\title{
Vistas in the domain of organoselenocyanates
}

\author{
Saad Shaaban,* Mahmoud A. Arafat, and Wafaa S. Hamama* \\ Department of Chemistry, Faculty of Science, Mansoura University, 23768 Mansoura, Egypt \\ E-mail: drsaad chem@mans.edu.eg,wshamama53@gmail.com
}

\begin{abstract}
In this review we compile and update recent developments in the synthesis, chemical properties, and biological importance of organic selenocyanates. The diverse synthetic routes to organoselenocyanates are described in the first part, including direct and indirect cyanoselenation. In the second part, the chemical reactions of organoselenocyanate are discussed. These included oxidation-reduction reactions. Further reactions included addition to the selenocyanate carbonitrile group, and reactions accompanied with cyanide group loss. These compounds exhibit anticancer, antioxidative, antileishmanial, antimutagenic and chemopreventive properties. The reported biological properties of this group of compounds are summarized in the last part.
\end{abstract}

Keywords: Organoselenocyanates, potassium selenocyanate, triselenium diselenide, selenocyanation, antileishmania

\section{Table of Contents}

1. Introduction

2. Synthetic Aspects of Organoselenocyanates

2.1. Direct cyanoselenation

2.1.1. Cyanoselenation using potassium selenocyanate

2.1.2. Cyanoselenation using triselenium dicyanide

2.1.3. Cyanoselenation using dicyanodiselenide

2.1.4. Cyanoselenation using copper diselenocyanate

2.2. Indirect cyanoselenation

2.2.1. Cyanoselenation via rearrangement of isoselenocyanates

2.2.2. Cyanoselenation via the reaction of alkyl magnesium halides, selenium powder and cyanogen bromide

3. Reactions of Organic Selenocyanates

3.1. Reduction of organic selenocyanates 
3.2. Oxidation of organic selenocyanates

3.3. Addition reactions to the carbonitrile group

3.4. Reactions accompanied with cyanide group loss

4. Biological Activities

5. Conclusion

References

\section{Introduction}

Organic compounds in which chalcogen atoms (oxygen, sulphur, selenium or tellurium) are connected on one side to a hydrocarbon substituent and on the other side to a carbonitrile group are called cyanate $(\mathrm{OCN})$, thiocyanate $(\mathrm{SCN})$, selenocyanate $(\mathrm{SeCN})$, and tellurocyanate $(\mathrm{TeCN})$, respectively. Organocyanates are relatively unstable, difficult to prepare and handle. On the other hand, organothiocyanates are being utilized as intermediates in organic chemistry because of their relative stability. The chemistry of organothiocyanates has been the subject of several outstanding monographs and reviews. ${ }^{1-5}$ They have recently received wide attention due to their cancer chemopreventive properties. ${ }^{6,7}$ These compounds play a leading role in organoselenium chemistry as they are stable and readily available. Indeed, they are efficiently metabolized to selenols and diselenides and therefore thought to be favorable selenide precursors. $^{8}$

Although preparative methods as well as the chemical properties of organic selenocyanates have been reviewed before, most of these reviewed citations are three decades old., 90 Furthermore, several new studies providing extensive new knowledge have recently been published. Therefore, rather than dwell further on the triumphs of the past, this survey aims to compile and update recent developments in the synthesis, chemical properties and biological importance of organoselenocyanates. Our aim here is a comprehensive survey of recent literature reports on the current state of the art concerning the chemistry and biology of these compounds. We have tried to avoid duplicating the content of previous reviews, although some work is discussed again when necessary to the discussion and to serve to illustrate a particular reaction category or strategy.

\section{Synthetic Aspects of Organoselenocyanates}

There are several known methods for the synthesis of organic selenocyanates. These methods can be classified into direct and indirect selenocyanation. 


\subsection{Direct cyanoselenation}

This can be performed by direct reaction with a selenocyanating agent such as potassium selenocyanate, triselenium dicyanide (TSD), dicyanodiselenide or copper diselenocyanate $\left(\mathrm{Cu}(\mathrm{SeCN})_{2}\right)$ in an appropriate solvent.

2.1.1. Cyanoselenation using potassium selenocyanate. Nucleophilic cyanoselenation using potassium selenocyanate is the most common and preferred method used for the incorporation of selenocyanate group into organic compound backbones. This can be done either by the reaction with alkyl/aryl halides, sulfonyl/tosyl derivatives, diazonium salts, olefins or organosilanes.

2.1.1.1. Reaction of potassium selenocyanate with alkyl and aryl halides. This reaction is applicable to diverse functionalities (e.g. alkyl, aryl, allylic, propargylic, and natural compounds). Indeed, the reaction is usually performed under mild conditions using ethanol, acetone, dimethylformamide or acetonitrile as solvent. It is found that the reaction can also be improved under irradiation (microwave or ultraviolet), using two-phase systems or by using a suitable catalyst (e.g. a Lewis acid).

The reaction of potassium selenocyanate with the iodo derivative $\mathbf{1}$ in acetone afforded the corresponding selenocyanate $\mathbf{2}$ in $93 \%$ yield. The reaction proceeded via nucleophilic substitution of the iodine by the selenocyanate anion at the selenium atom (Scheme 1). ${ }^{11}$<smiles>CCCNC(=O)[C@H](Cc1ccccc1)NC(=O)O</smiles>

1

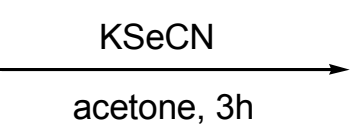

acetone, $3 \mathrm{~h}$<smiles>N#[Se]CCNC(=O)[C@H](Cc1ccccc1)NC(=O)O</smiles>

2

\section{Scheme 1}

Treatment of ethanolic solutions of hydrazonoyl chloride 3 with potassium selenocyanate gave the corresponding non-isolable hydrazone selenocyanates which cyclized to give the selenadiazolimine derivatives 4 in good yields (72-78 \%) (Scheme 2). ${ }^{12}$ 


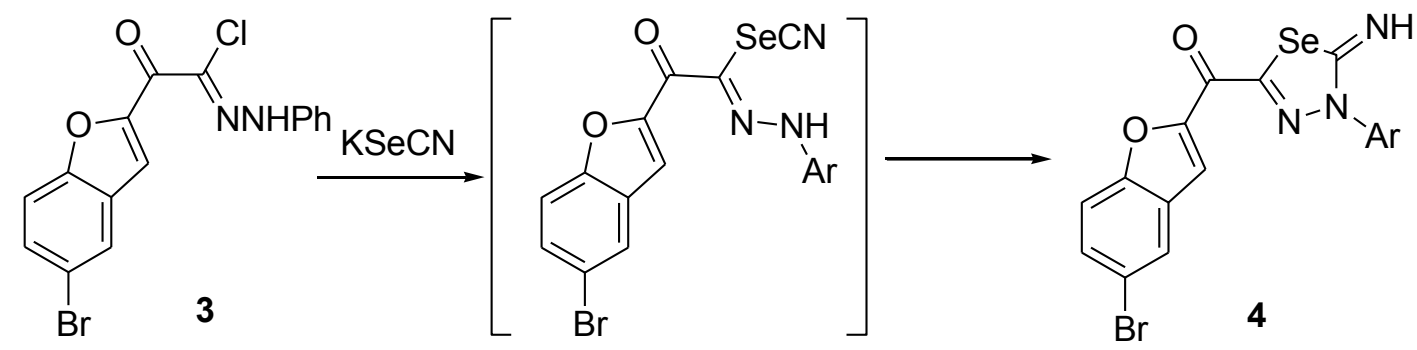

$\left[\mathrm{Ar}=\mathrm{C}_{6} \mathrm{H}_{5}, 4-\mathrm{CH}_{3} \mathrm{C}_{6} \mathrm{H}_{4}\right]$

\section{Scheme 2}

Furthermore, selenocyanate $\mathbf{6}$ was obtained in 53\% yield by refluxing potassium selenocyanate with iodohydrin $\mathbf{5}$ in acetone (Scheme 3 ). ${ }^{13}$

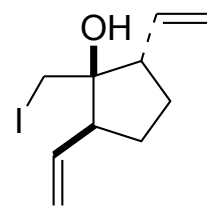

5

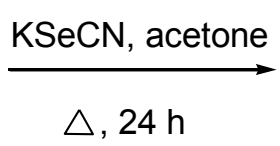

$\triangle, 24 \mathrm{~h}$

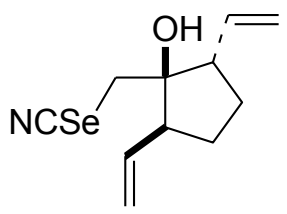

6

\section{Scheme 3}

Desai et al. ${ }^{14}$ reported the synthesis of $N$-phenyl-6-selenocyanatohexanamide 8 , a histone deacetylase inhibitor, in $64 \%$ yield via the reaction of 6-bromo- $N$-phenylhexanamide 7 with potassium selenocyanate in acetonitrile at ambient temperature (Scheme 4).

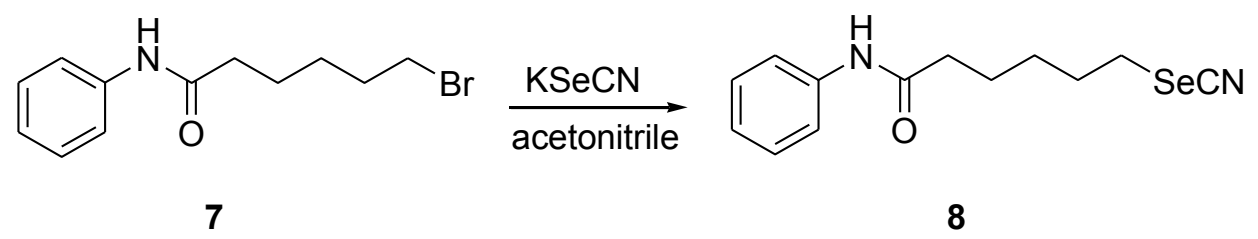

\section{Scheme 4}

This reaction was also applied to the synthesis of mixed macrocyclic selenoethers $\mathbf{1 1}$ and $\mathbf{1 2}$ via cyclization of the corresponding bis-selenocyanate precursor 10. The latter was prepared in 
$62 \%$ yield by careful addition of bis-(2-bromoethyl)ether 9 to an acetone solution containing potassium selenocyanate (Scheme 5). ${ }^{15}$

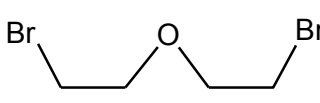

9

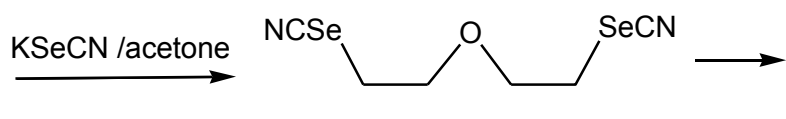

10
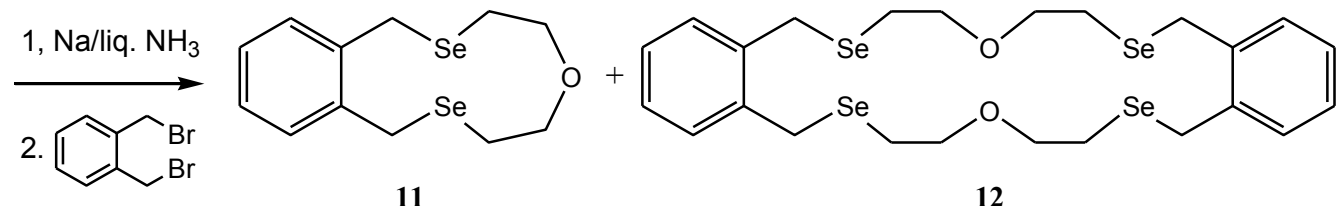

11

12

\section{Scheme 5}

Masked phosphonioalkylselenoate ligands 14, used for the preparation of phosphonioalkylselenoate-functionalised gold nanoparticles, were prepared by the reaction of (bromoalkyl)triphenylphosphonium bromide $\mathbf{1 3}$ with potassium selenocyanate in aqueous ethanol (Scheme 6). ${ }^{16}$

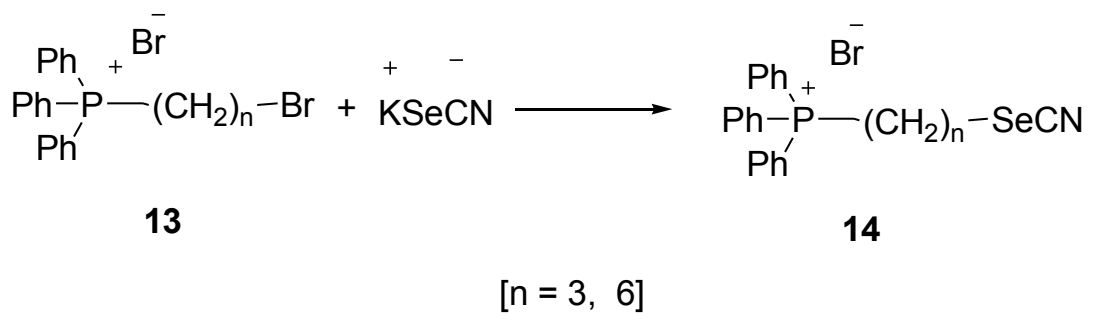

\section{Scheme 6}

15-Selenocyanochrysophanols 17 were prepared from the naturally occurring aloe-emodin 15. The latter was brominated using carbon tetrabromide and triphenylphosphine in tetrahydrofuran to give the corresponding bromide 16 ( $82 \%$ yield), which in turn was used as the starting material for the introduction of selenocyanate group (65-86\% yields) by the reaction with potassium selenocyanate. The cytotoxic effects of these compounds were evaluated using HCT 116 and Hep G2 cancer cell lines and they were found to possess much more potent effects than the parent aloe-emodin 15 (Scheme 7). ${ }^{17}$ 
<smiles>[R]Oc1cccc2c1C(=O)c1c(O[R20])cc(CO)cc1C2=O</smiles>

15

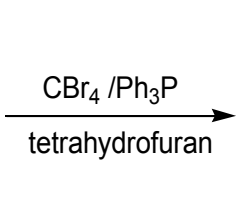

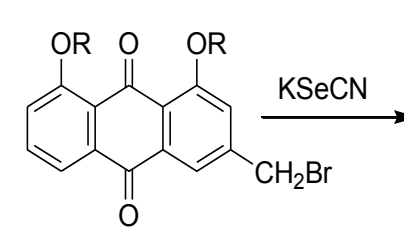

16

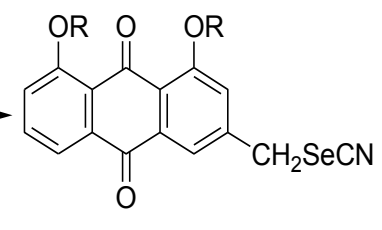

17

$$
[\mathrm{R}=\mathrm{H} \text {, hexyl] }
$$

\section{Scheme 7}

1-Phenyl-2-selenocyanatoethanone (19), known as useful building blocks for the synthesis of selenium heterocycles, was prepared in fair yields $(33 \%)$ by the reaction of phenacyl bromides (18) with potassium selenocyanate in acetone (Scheme 8). ${ }^{18}$

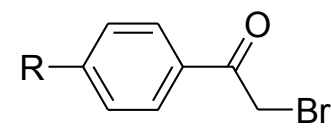

18

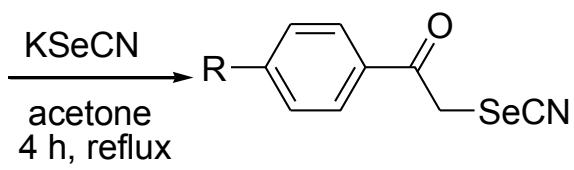

19

$[\mathrm{R}=\mathrm{H}, \mathrm{Cl}, \mathrm{Br}]$

\section{Scheme 8}

Sk et al. ${ }^{19}$ reported the synthesis of different organoselenocyanates possessing 1,8naphthalimide moiety $\mathbf{2 1}$ and evaluated their preventive potential for cadmium induced hepatic lipid peroxidation and oxidative stress. These compounds were able to prevent the oxidative stress in mice induced by cadmium and enhanced the mice ability to restore hepatic lipid peroxidation level and they showed also hepatoprotective activity. The target compounds were synthesized in good yields (68-89\%) via nucleophilic substitution of the bromides 20 with selenocyanate using potassium selenocyanate in acetone (Scheme 9). ${ }^{19}$

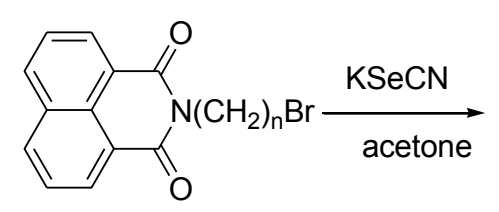

20<smiles>N#CCCCCCN1C(=O)c2cccc3cccc(c23)C1=O</smiles>

21

$[n=2-5]$

\section{Scheme 9}


Once more, Sk and his group ${ }^{20}$ reported the synthesis of spiro[tetralin-1,3'-pyrrolidine] based organoselenocyanates $\mathbf{2 3}$ and evaluated their inhibitory activity against cadmium induced toxicity in Swiss albino mice. The preadministration of these compounds was accompanied by an improvement in the hepatotoxicity with exception that naphthalimide containing selenocyanates were more active. This was in agreement with Sk et al. ${ }^{19}$ previous report where these compounds were able to retain redox homeostasis and exhibited hepatoprotective activity. ${ }^{19}$

The spiro selenocyanato tetralin-1,3'-pyrrolidines $\mathbf{2 3}$ were obtained in $75-80 \%$ yields via nucleophilic substitution reaction of the corresponding bromide derivatives 22 with potassium selenocyanate in anhydrous tetrahydrofuran (Scheme 10). ${ }^{20}$<smiles>CCCCCCCCCCCCCCCCCN1C(=O)CC2(CCCc3cc(OC)ccc32)C1=O</smiles>

22

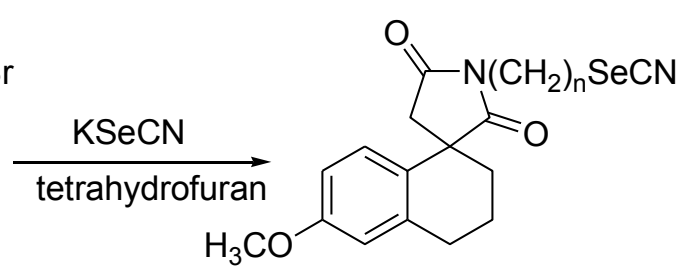

23

$[\mathrm{n}=2,3,4$ and 5$]$

\section{Scheme 10}

In a similar study, Roy et $a .^{21}$ described the synthesis of a series of substituted naphthalimide-based organoselenocyanates and investigated their corresponding hepatotoxicity, nephrotoxicity and also their ability to modulate the levels of phase II detoxifying and antioxidant enzymes such as glutathione-S-transferase (GST), superoxide dismutase (SOD), catalase (CAT), glutathione peroxidase (GPx), thioredoxin reductase (TRxR) and nonenzymatic antioxidant like reduced glutathione (GSH) levels in liver. Selenocyanato-isoquinolines 25 were prepared from bromoalkyl-naphthalimides $\mathbf{2 4}$ upon reaction with potassium selenocyanate in acetone (51-74\% yields) (Scheme 11). ${ }^{21}$

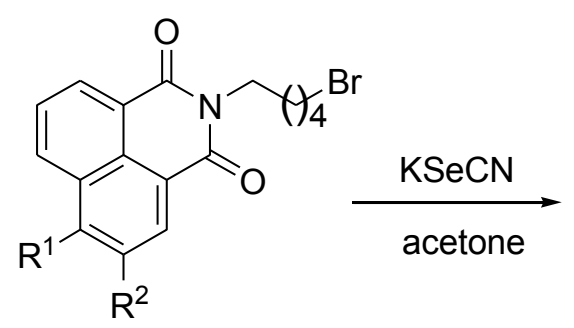

24<smiles>[R]c1cc2c3c(cccc3c1[R])C(=O)N(C[As][As])C2=O</smiles>

25

$$
\left[\mathrm{R}^{1}=\mathrm{H}, \mathrm{Cl} ; \mathrm{R}^{2}=\mathrm{H}, \mathrm{NO}_{2}\right]
$$

\section{Scheme 11}


Mamedov and his colleagues ${ }^{22}$ also reported the synthesis of 3-(3-phenyl-1selenocyanatopropyl)quinoxalin-2(1H)-ones 27 by the reaction of potassium selenocyanate with chlorophenylethylquinoxalinone 26. The reaction proceeded using excess of potassium selenocyanate in dimethylformamide at $40^{\circ} \mathrm{C}$ and the yield was up to $81 \%$ (Scheme 12). ${ }^{22}$

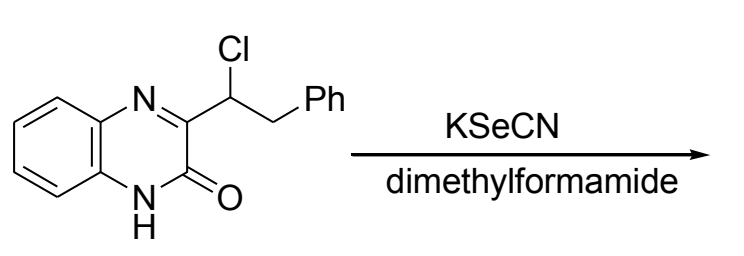

26<smiles>N#C[Se]C(Cc1ccccc1)c1nc2ccccc2[nH]c1=O</smiles>

27

\section{Scheme 12}

Benzyl selenocyanates $\mathbf{3 0}$ were obtained from the reaction of the reaction of benzylic bromides 28 with potassium selenocyanate in acetonitrile. ${ }^{23}$ The products were pure enough and obtained in satisfactory yields (up to 70\%). When acetone was used as the solvent, 31 were obtained. This was interpreted as the formation of a second nucleophile $\mathbf{2 9}$ which further reacted with benzylic halides leading to the formation of 31. It was also postulated that long reaction time was the cause of this side reaction (Scheme 13). ${ }^{23}$

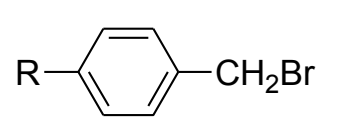

28

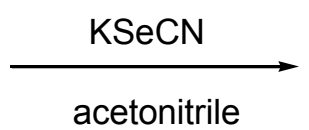

acetonitrile<smiles>[R]c1ccc(C[SeH]#N)cc1</smiles>

30

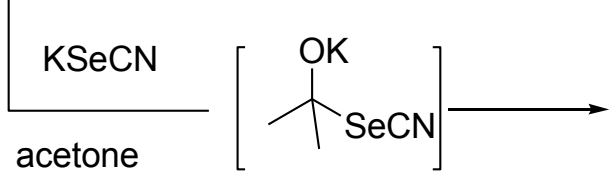

29<smiles>[R]c1ccc(COC(C)(C)[Se]C#N)cc1</smiles>

\section{Scheme 13}


Very recently, Krishnegowda et al. ${ }^{24}$ described the synthesis of 5,7-dibromoisatin containing selenocyanate groups 34 and 36. The later were obtained in a good yield (67 and $76 \%$, respectively) via the nucleophilic substitution of potassium selenocyanate with 5,7-dibromo- $N$ chloroalkylisatin 33 and $-N$-(4-bromomethyl)benzylisatin 35, respectively (Scheme 14). These compounds were evaluated for their cytotoxicity against colon, breast, lung and melanoma cancer cells and were reported to display good in vitro activity against breast cancer cells (MCF7) compared to their thiocyanate analogs. Furthermore, the compounds were found to inhibit tubulin polymerization as vinblastine sulfate (antimicrotubule drug used to treat certain kinds of cancer). This further support the hypothesis that a combination of indoles and selenocyanates might lead to a novel dual targeted inhibitors which may further developed as future drugs. ${ }^{24}$

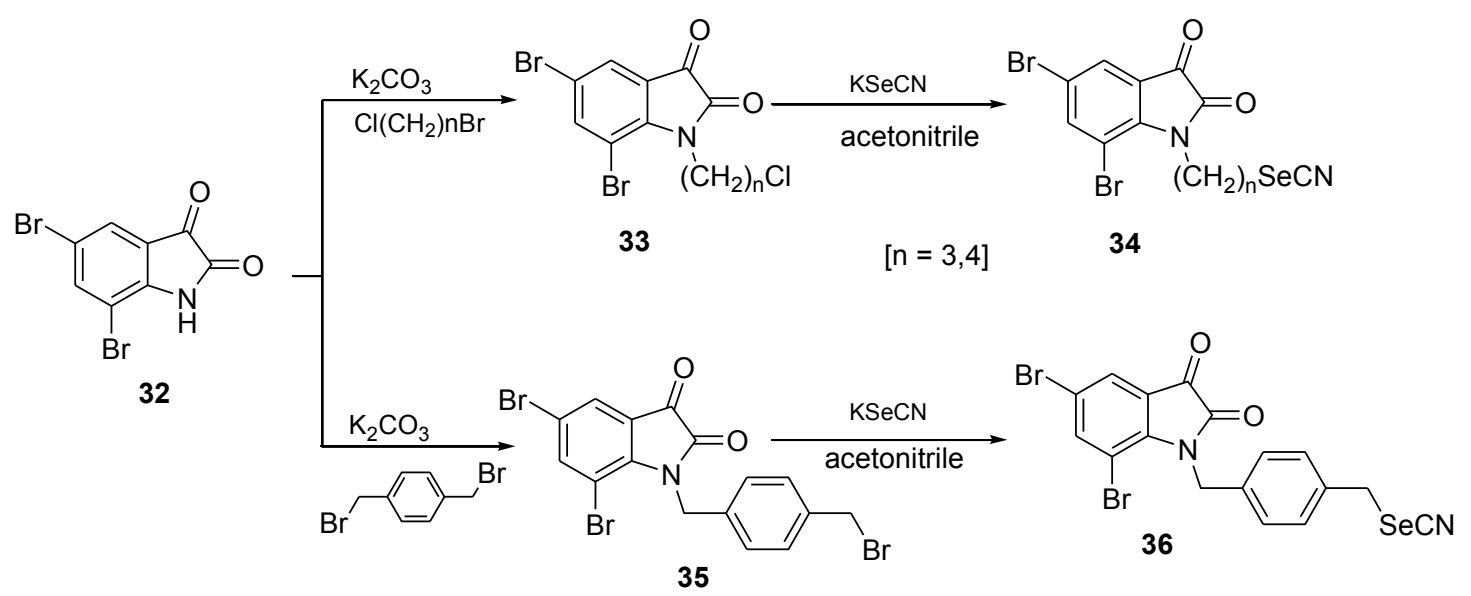

\section{Scheme 14}

Different aromatic selenocyanates 38 were obtained (15-81\% yields) by refluxing haloarenes or haloalkylarenes 37 with potassium selenocyanate in acetone (Scheme 15). ${ }^{25}$ It is noteworthy that the substrate nature played an important role in determining the reaction progress and rate. Within this context, electron-withdrawing substituents facilitate the nucleophilic selenocyanate anion attack by stabilizing the formed negative charge via mesomeric and inductive effect. ${ }^{25}$

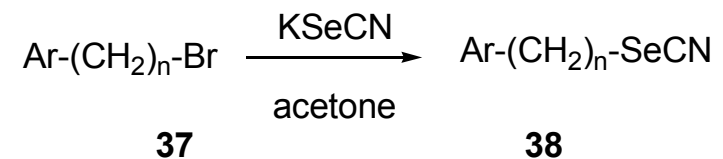

[Ar = 4-aminophenyl, 4-bromophenyl, 4-nitrophenyl, 4-methoxyphenyl; $\mathrm{n}=0$, 1, 2]

\section{Scheme 15}


Allylic and propargylic selenocyanates (40) were also obtained in good yields (up to $80 \%$ ) by the reactions of allylic and propargylic bromides 39 with potassium selenocyanate in acetonitrile and at room temperature. ${ }^{26-31}$ It is worth noting that the replacement of dimethylformamide by acetonitrile led to byproduct minimization (Scheme 16). Indeed, the rate of the reaction may be increased either by irradiation (ultraviolet) or by using Lewis acids (e.g. copper(I) iodide dissolved in warm hexamethylphosphoric triamide). ${ }^{32-35}$ On the other hand, alkenyl and alkynyl halides were basically unreactive toward cyanoselenation under these conditions. ${ }^{33}$ This may be attributed to the induced repulsion between the electrons of the double/triple bond and the selenocyanate anion. ${ }^{33}$

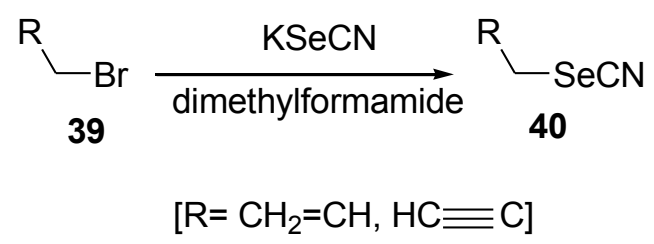

\section{Scheme 16}

Besides, $N$-benzyl- $\beta$-amino diselenides 43 were also synthesized from sulfamidates in a multistep one-pot reaction using potassium selenocyanate and benzyltriethylammonium tetrathiomolybdate in acetone. The non isolable selenocyanate key intermediate $\mathbf{4 2}$ was in situ formed via regioselective ring opening of sulfamidate 41 using potassium selenocyanate. The corresponding $N$-benzyl- $\beta$-aminodiselenide derivative $\mathbf{4 3}$ was obtained upon reductive dimerization followed by hydrolysis by treatment with tetrathiomolybdate and hydrochloric acid in quantitative yield (up to $99 \%$ ) (Scheme 17). ${ }^{36}$

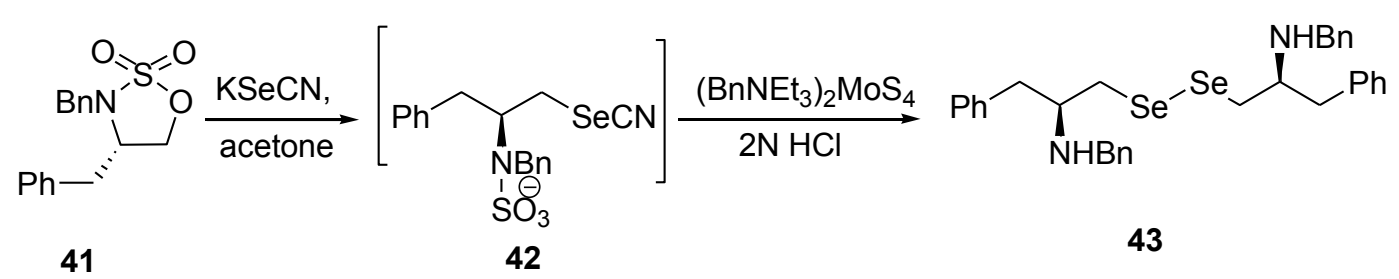

\section{Scheme 17}

Naturally occurring furostanol derivatives 45 modified by the incorporation of a selenocyanate group at position 26 were synthesized in a multistep reaction of $\mathbf{4 3}$ and potassium selenocyanate in fair yield (24\%) (Scheme 18). ${ }^{37,38}$ The cytotoxic activity of this compound was 
evaluated against HCT 116 and Hep G2 cancer cells. Interestingly, 45showed higher effects than the parent natural compound on both HCT 116 and Hep G2 cells. ${ }^{37,38}$

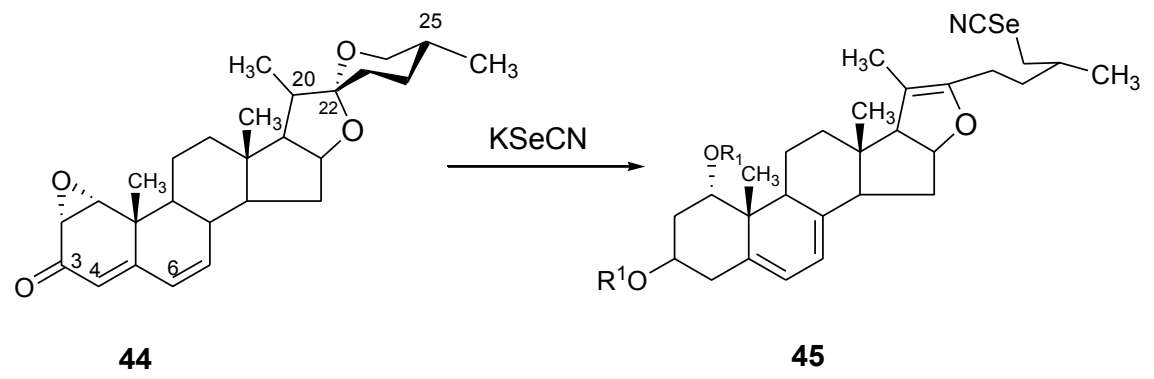

$[\mathrm{R}=\mathrm{H}, \mathrm{Ac}]$

\section{Scheme 18}

Viñas-Bravo et al. ${ }^{39}$ reported the synthesis of selenocyanatofurostan 47 in high yields (90\%) via treatment of sapogenins $\mathbf{4 6}$ with a mixture of acetic/trifluoroacetic mixed anhydride, borontrifloride ether and potassium selenocyanate at room temperature (Scheme 19). ${ }^{39}$

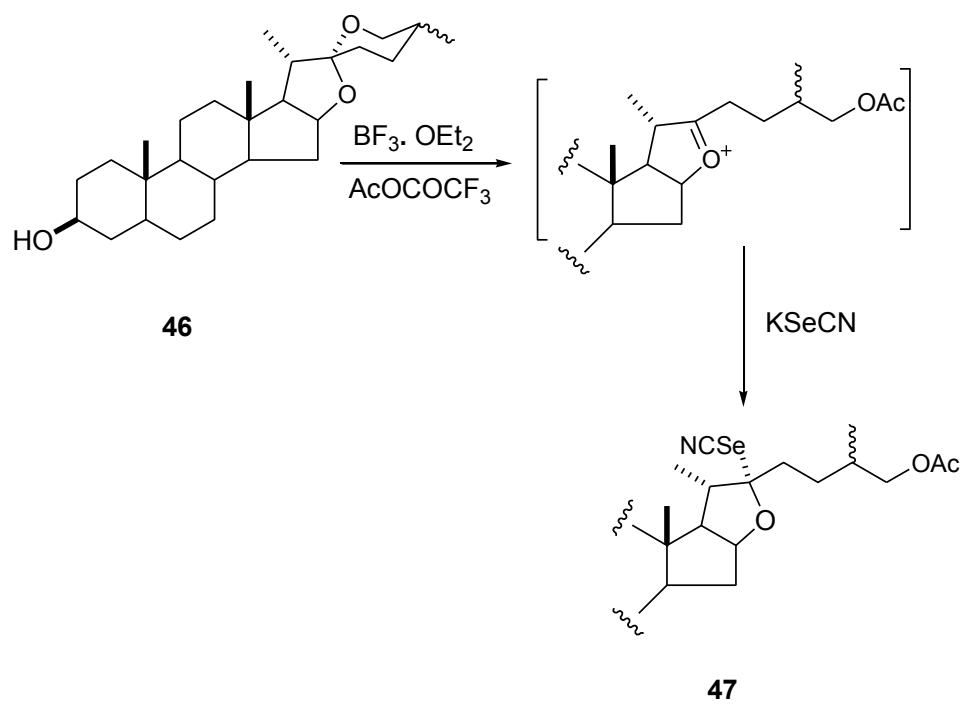

\section{Scheme 19}

Another report by Desai et $a .^{40}$ described the synthesis of Selenocoxib-1 (49), a selenocyanate analogue of the sulfonamide nonsteroidal anti-inflammatory drug Celecoxib (Scheme 20). The reaction of chloro-derivative 48 with potassium selenocyanate in acetone afforded the corresponding selenocyanate 49 in $57 \%$ yields. Interestingly, Selenocoxib-1 was 
more efficient than Celecoxib itself in controlling the tumor growth in the short-term PAIII transplantable LW model and provided greater inhibition of invasive prostate cancer growth at lower dose. $^{40}$

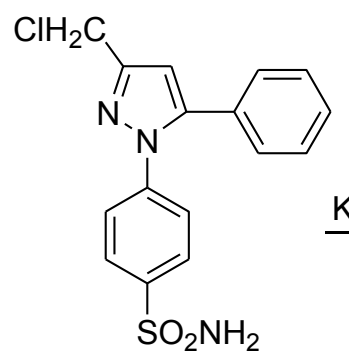

48

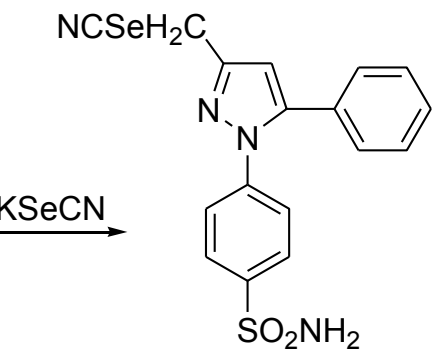

49

\section{Scheme 20}

2.1.1.2. Reaction of potassium selenocyanate with sulfonate/tosylates sulfonyl/tosyl derivatives. 1,1'-Di-(2-selenocyanatoethyl)cyclohexane (51) was obtained in 87\% yield from the reaction of (1,1'-di-(2-methane-sulfonyloxyethyl)cyclohexane) (50) with excess potassium selenocyanate in anhydrous acetone and at $56{ }^{\circ} \mathrm{C}$ (Scheme 21$) .{ }^{41}$

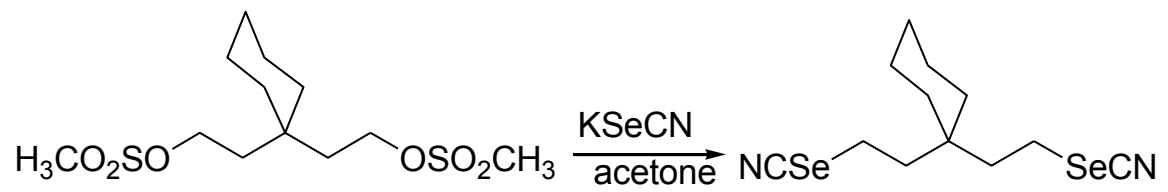

50

51

\section{Scheme 21}

Similarly, heating equimolar amounts of 3-butyn-1-yl-p-toluenesulfonate (52) and potassium selenocyanate in acetonitrile for $3 \mathrm{~h}$ afforded $\mathbf{5 3}$ in 83\% yields (Scheme 22). ${ }^{42}$

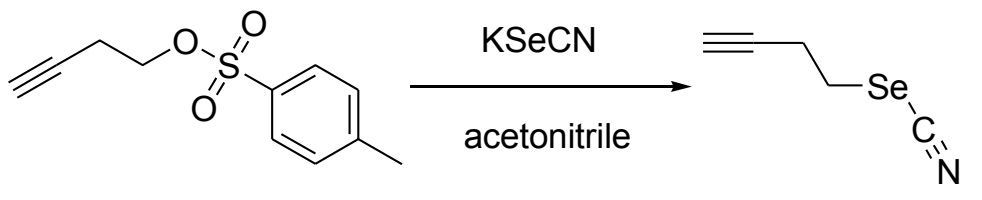

52

53

\section{Scheme 22}


Tosylates could also be used instead of sulfonates for the preparation selenocyanates. In this context, allenyl selenocyanates 55 were synthesized (in 60-80 \% yields) by the reaction of their corresponding tosylates 54 with potassium selenocyanate in acetonitrile (Scheme 23). ${ }^{43}$

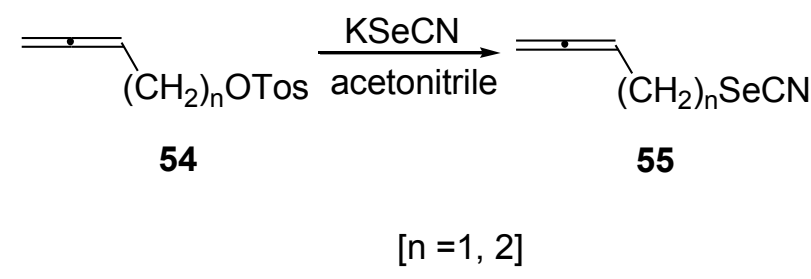

\section{Scheme 23}

Furthermore, Jacob et al. also reported the synthesis of benzyl selenocyanates $\mathbf{5 7}$ from benzyl tosylates 56 using the same reaction conditions. Nevertheless, the yield was low and accompanied by formation of colloidal red selenium (Scheme 24). ${ }^{23}$

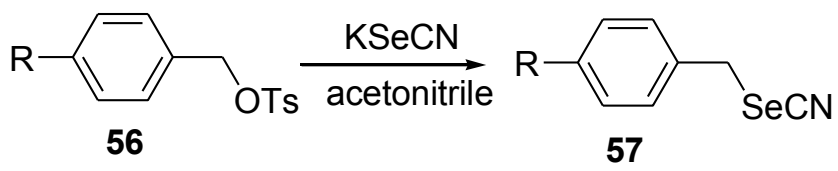

$$
[R=H, F, M e, M e O, t-B u]
$$

\section{Scheme 24}

Mesylation of $\mathbf{5 8}$ followed by introduction of the crucial selenocyanate moiety via SN2, afforded the corresponding selenocyanate 59 in fair yield (29\%) (Scheme 25). ${ }^{44}$

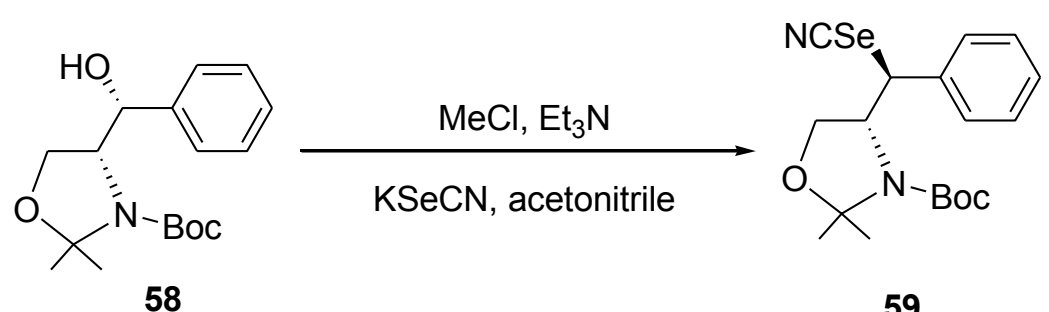

\section{Scheme 25}


2.1.1.3. Reaction of potassium selenocyanate with diazonium salts. Primary aromatic amines are convenient starting building blocks for the synthesis of organoselenocyanates. ${ }^{45,46}$ For instance, diazotized anilines $\mathbf{6 1}$ reacted with potassium selenocyanate to give the corresponding aromatic selenocyanates 62. These compounds were mostly obtained in low yields due to the decomposition of potassium selenocyanate by the acid traces remaining from the diazotization step. The reaction was accordingly performed in a buffered solution (sodium acetate; $\mathrm{pH}=5.5$ ) and the yield was moderately improved (38-46\%) (Scheme 26). ${ }^{45,46}$

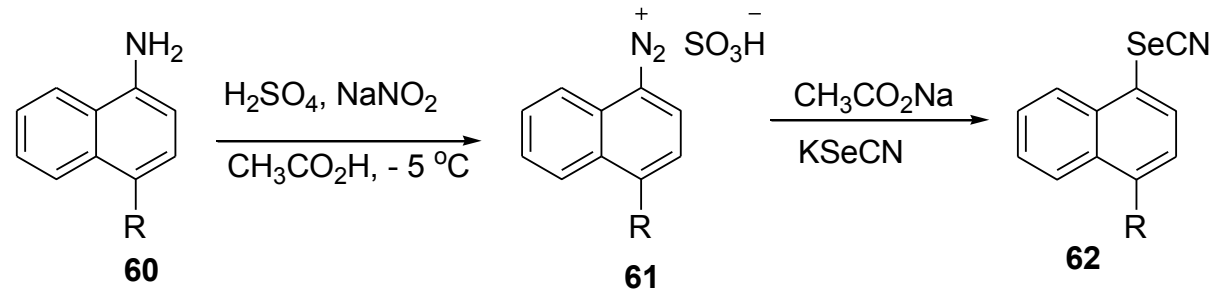

$\left[\mathrm{R}=\mathrm{H}, \mathrm{Cl}, \mathrm{Br}, \mathrm{NO}_{2}\right]$

\section{Scheme 26}

2.1.1.4. Reaction of potassium selenocyanate with indoles and olefins. Nair et al. ${ }^{47}$ reported that indoles 63 may undergo cyanoselenation in a good yield (72\%) using cerium(IV) ammonium nitrate (CAN) and potassium selenocyanate in methanol (Scheme 27).

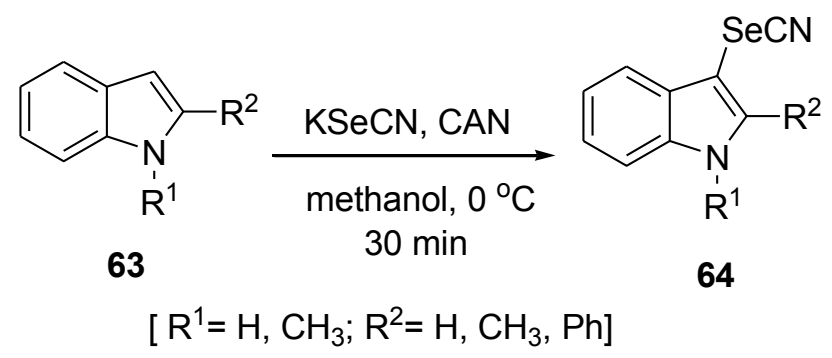

\section{Scheme 27}

The same result was obtained with 1-methylpyrrole (65); however, the yield was lower (25\% yield) (Scheme 28). ${ }^{47}$ 


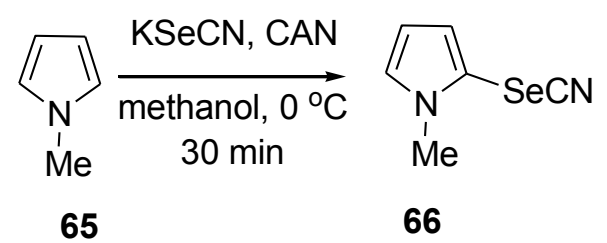

\section{Scheme 28}

Selenocyanation of styrenes and vinyl naphthalenes 67 in the presence of CAN using potassium selenocyanates afforded the corresponding selenocyanates $\mathbf{6 8}$ in a moderate yields (46-67\%) (Scheme 29). ${ }^{47}$

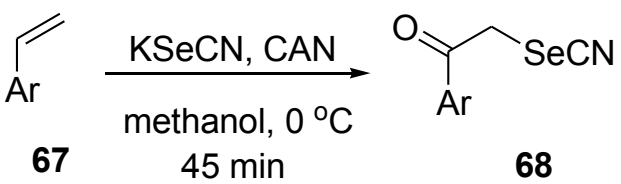

[Ar= 4-tolyl, 1-naphthyl, 2-naphthyl]

\section{Scheme 29}

2.1.1.4. Reaction of potassium selenocyanate with organosilanes. Regioselective $\alpha$-substitution of allylic silanes $\mathbf{6 9}$ and $\mathbf{7 1}$ with a selenocyanate group using potassium selenocyanate took place in methanol to give the corresponding allylic selenocyanates $\mathbf{7 0}$ and $\mathbf{7 2}$ in moderate yields (up to $72 \%$ ) (Scheme 30$).{ }^{48}$ It is worth noting that readily available allylic halides are favorably preferred than allylic silanes as the selenocyanates are obtained from allylic halides in higher yields. ${ }^{26-31}$

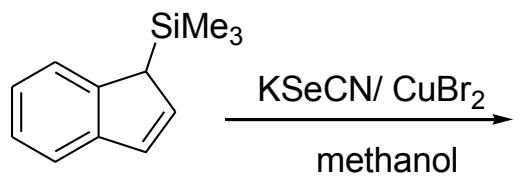

69<smiles>N#[Se]C1C=Cc2ccccc21</smiles>

70

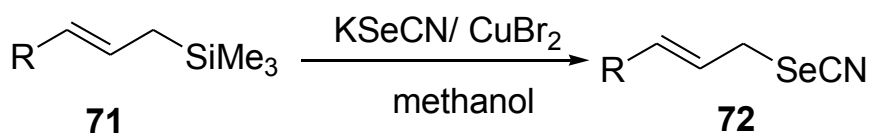

$$
[\mathrm{R}=\mathrm{H}, \mathrm{Ph}]
$$

\section{Scheme 30}


2.1.1.5. Reaction of potassium selenocyanate with metal-based complexes. The Meggers, Murray and Klingele goups ${ }^{49-55}$ exploited the substitutionally inert metal complexes as sophisticated scaffolds for the design of enzyme, protein and lipid kinase inhibitors via targeting their active sites. They demonstrated that octahedral metal coordination geometries provide novel scope to implement specific molecular scaffolds that can fit into protein pockets. Furthermore, linear gold complex $\mathbf{7 8}$ was used as a model for theoretical studies and for determining the electronic characteristics of metal-ligand bonding through structural studies. The selenocyanate group was introduced in order to increase the inhibition activity. This was performed by heating the metal based complex with potassium selenocyanate in dimethylformamide, acetonitrile or methanol at $95^{\circ} \mathrm{C}$ for $12 \mathrm{~h}$ (Scheme 31). ${ }^{49-57}$

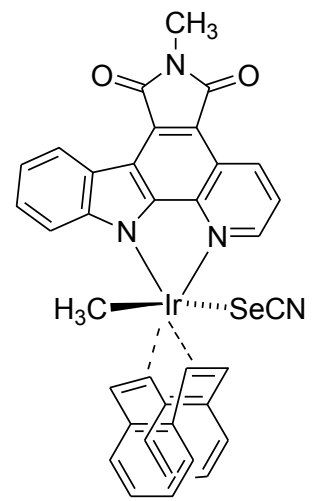

73

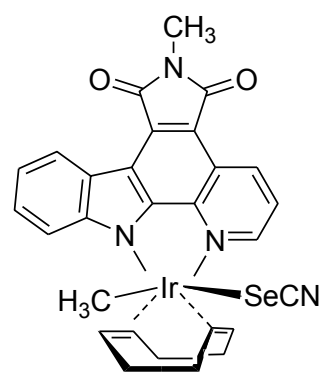

76

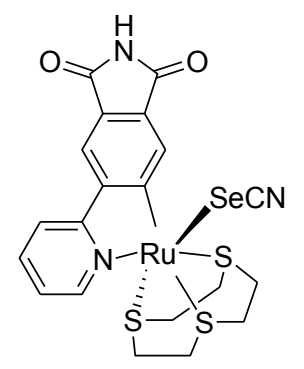

74

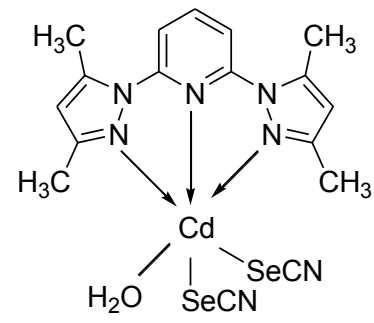

77

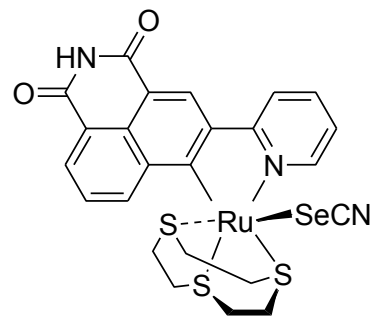

75

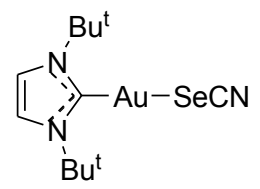

78

\section{Scheme 31}

2.1.2. Cyanoselenation using triselenium dicyanide. The TSD reagent $\left(\mathrm{Se}(\mathrm{SeCN})_{2}\right)$ was used to insert the selenocyanate group directly into the scaffold of some active methylene compounds, arenes with free para positions and indoles with a free 3-position and dimedone to give the corresponding selenocyanates 79-81 (Scheme 32). ${ }^{58}$ The most convenient method for the preparation of TSD is by oxidative coupling of malononitrile with selenium dioxide. Dimethylsulfoxide or dimethylformamide is the usual solvent used. ${ }^{25,59}$ TSD could also be 
prepared via the oxidation of potassium selenocyanates using suitable oxidizing agents (e.g. dinitrogen tetroxide, iodine pentafluoride, chlorine, bromine or iodine). ${ }^{60}$

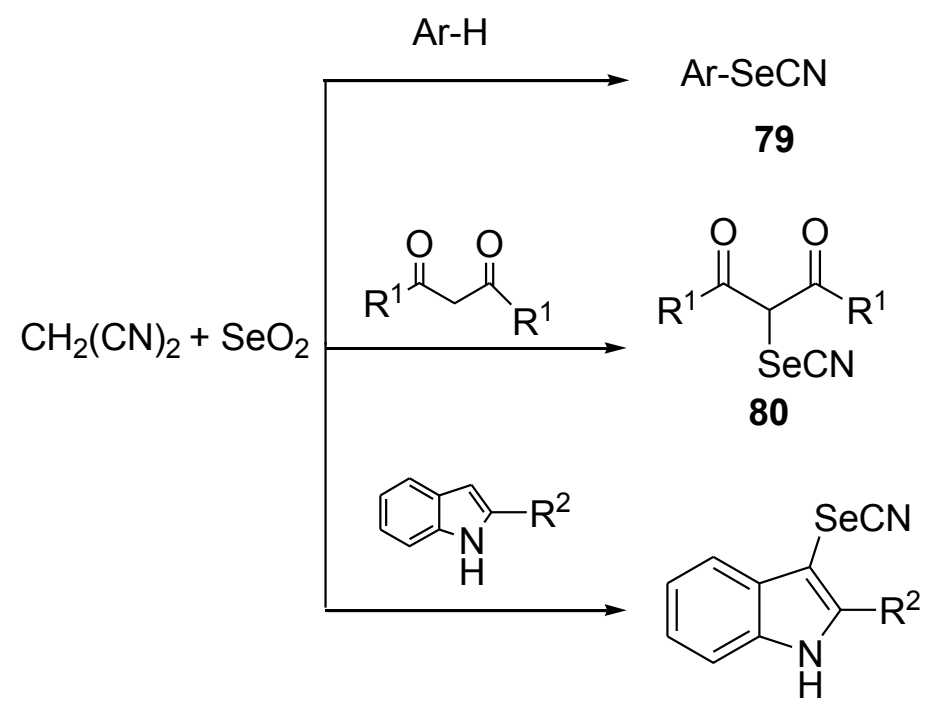

81

[Ar = 4-aminophenyl, dimethylaminophenyl, 4-amino-3-methylphenyl, 4-amino-3-carboxyphenyl; $\left.\mathrm{R}^{1}, \mathrm{R}^{2}=\mathrm{H}, \mathrm{Me}, \mathrm{COOEt}\right]$

\section{Scheme 32}

2.1.3. Cyanoselenation using dicyanodiselenide. Selenocyanogen, $(\mathrm{SeCN})_{2}$, prepared from the reaction of silver selenocyanate with iodine, ${ }^{61}$ was used for the synthesis of various selenocyanates which could not be prepared by any of the previously mentioned approaches. Thus, allenyl selenocyanate $\mathbf{8 3}$ was prepared by the reaction of selenocyanogen with propargyl tri-nbutylstannane 82 via a propargyl-allenyl rearrangement in a $55 \%$ yield (Scheme 33). ${ }^{43}$

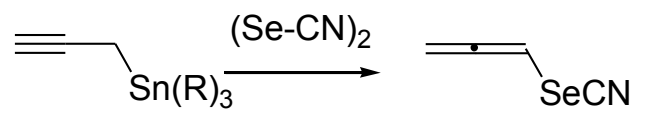

82

$[\mathrm{R}=\mathrm{Ph}, \mathrm{Bu}]$

\section{Scheme 33}


2.1.4. Cyanoselenation using copper diselenocyanate. Disubstituted azulenes 84 reacted with copper diselenocyanate to furnish the corresponding selenocyanate $85 .^{62}$ It was found that the second substituent plays a determining role in the rate of the reaction (Scheme 34).

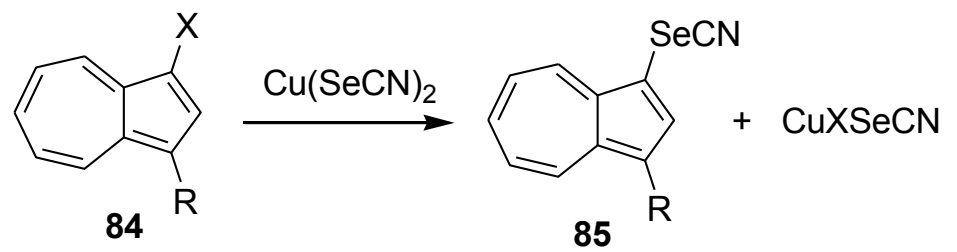

$\left[\mathrm{R}=\mathrm{MeO}, \mathrm{Ph}, \mathrm{COPh}, \mathrm{SO}_{2} \mathrm{Ph}, \mathrm{NO}_{2} ; \mathrm{X}=\mathrm{Cl}, \mathrm{Br}, \mathrm{I}\right]$

\section{Scheme 34}

\subsection{Indirect cyanoselenation}

Selenocyanates could also be prepared in situ, without the use of a selenocyanating agent. This includes rearrangement of isoselenocyanates and reaction of alkyl magnesium halides with selenium powder and cyanogen bromide. Selenocyanates could also synthesized by other methods (e.g. electrolysis of selenocyanic acid salts, reaction of diselenides with mercury(II) cyanide and reaction of phenylselenenyl chloride with trimethylsilyl cyanide). ${ }^{63-67}$ These methods are quite old, were seldom used in the past (more than thirty years ago) and will not be discussed here. Their relevant references are cited in case the reader needs more details.

2.2.1. Cyanoselenation via rearrangement of isoselenocyanates. Reversible hetero-Cope rearrangements ([3,3]-sigmatropic shifts) of isoselenocyanate to isomeric selenocyanate usually take place thermally e.g. on flash vacuum thermolysis. ${ }^{68,69}$ For example, [3,3]-sigmatropic rearrangements of allylic (86) and propargylic (90) isoselenocyanates occurred upon heating to give the corresponding allylic $(\mathbf{8 7}, \mathbf{8 8})$, cyclopropyl (89) and allenyl (91) selenocyanates (Scheme 35). ${ }^{31,70-72}$ 


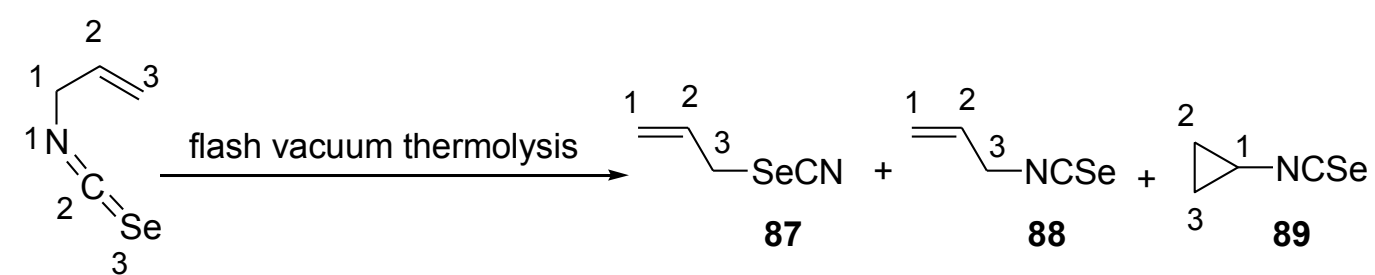

86

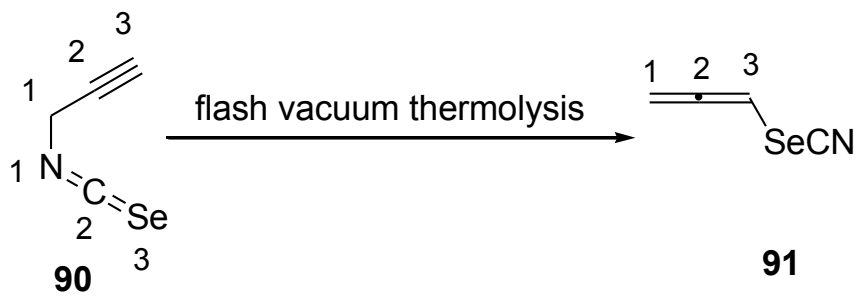

\section{Scheme 35}

Pentaphenylcyclopentadienyl isoselenocyanate (92) underwent isomerization to give the corresponding selenocyanate (93) via 1,5-sigmatropic rearrangement of the selenocyanate group around the cyclopentadiene ring (Scheme 36). ${ }^{68,73,74}$

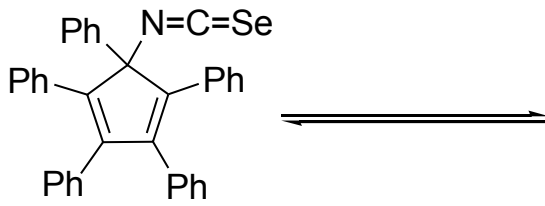

92<smiles>N#CC1(c2ccccc2)C(c2ccccc2)=C(c2ccccc2)C(c2ccccc2)=C1c1ccccc1</smiles>

93

\section{Scheme 36}

2.2.2. Cyanoselenation via the reaction of alkyl magnesium halides, selenium powder and cyanogen bromide. Guillemin et al. $^{43}$ reported the synthesis of 1-propynylselenocyanate 95 from reaction of the corresponding alkyl magnesium salt with selenium powder followed by the addition of cyanogen bromide (Scheme 37 ). ${ }^{43}$ 


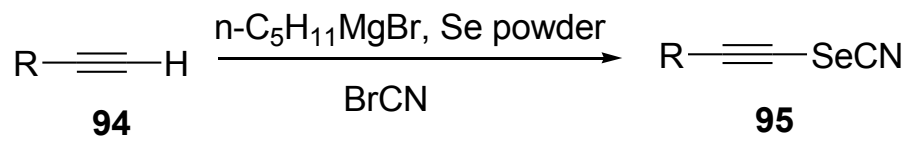

$[\mathrm{R}=\mathrm{H}, \mathrm{Me}]$

\section{Scheme 37}

\section{Reactions of Organic Selenocyanates}

Organoselenocyanates are characterized by their distasteful odors. They are colorless stable compounds and in most cases present as oil at room temperature. The spectrophotometric properties (e.g. infrared, NMR, photoelectron and microwave studies) were described in previous reports. $^{9,10}$

Recently, numerous organoselenium compounds have been synthesized employing organoselenocyanates. The latter can also be transformed into various selenoorganic derivatives including selenols, functionalized selenides (both symmetric and asymmetric) and diselenides. ${ }^{75,76}$ Indeed, alkenes, alkynes, alcohols, aldehydes and carboxylic acids could be also synthesized from organic selenocyanates. ${ }^{77-80}$ Nevertheless, some of these reactions were reported decades ago and are no longer used. These include the reaction with halogens, thiols, acids or selenols. ${ }^{81-84}$ Other obsolete reactions include the addition reaction of organoselenocyanates to alkenes, alkyne or enamines. ${ }^{85-89}$ These reactions will not be discussed here and the reader is directed to other reviews or monographs. 9,10

In the interest of clarity, recent organoselenocyanate reactions presented here have been subdivided into four sections: (i) reduction reactions; (ii) oxidation reactions; (iii) addition reactions to the carbonitrile group; and (iv) reactions accompanied with cyanide group loss.

\subsection{Reduction of organic selenocyanates}

Alkali metal hydrides such as sodium borohydride, lithium aluminum hydride, lithium hydride, dichloroaluminum hydride and sodium hydride have been used for the reduction of organoselenocyanates. The corresponding diselenides were obtained in quantitative yields, in case if insufficient reductant was used. The former could be further reduced in the presence of excess reductant to yield the corresponding selenol in acidic medium as shown in the case of ferrocenylalkyl-selenols (Scheme 38). ${ }^{43,75,76,90}$ 


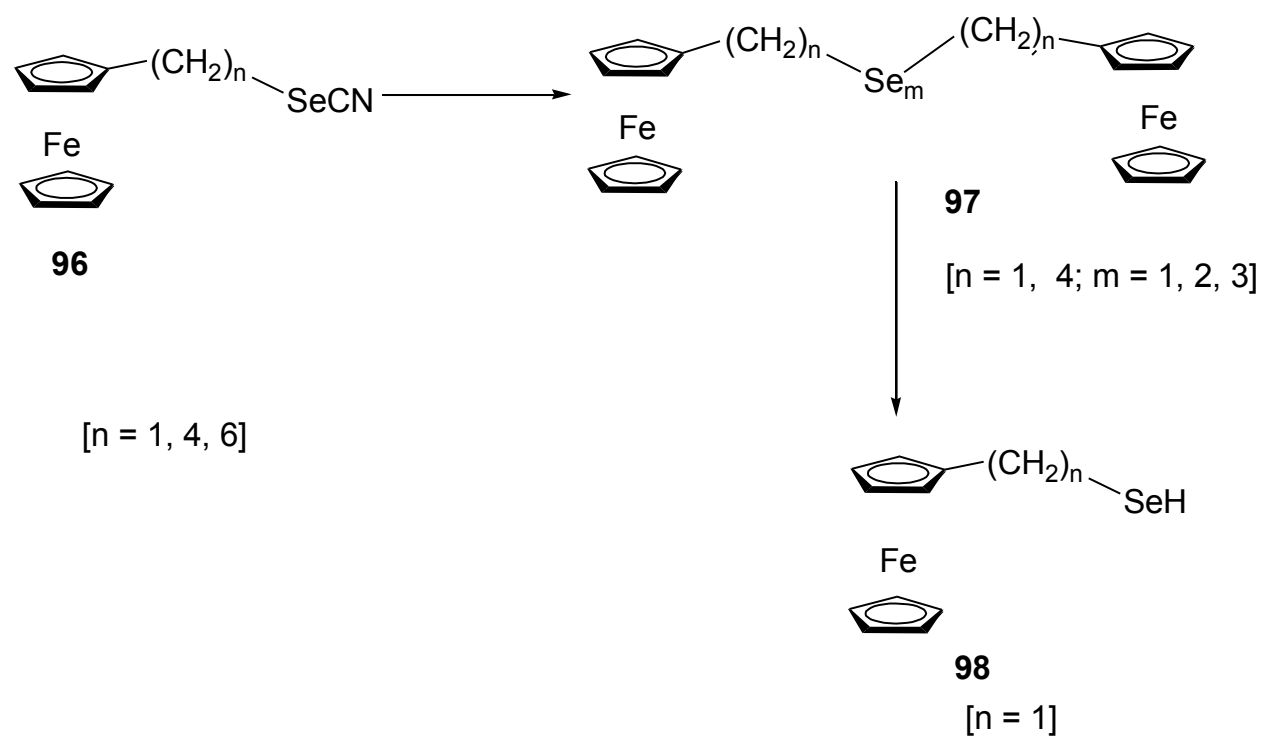

\section{Scheme 38}

The chemoselective reduction of unsaturated the allenylselenocyanate 99 was performed by dichloroaluminum hydride $\left(\mathrm{AlHCl}_{2}\right)$. This allowed the synthesis of allenylselenol $\mathbf{1 0 0}$ (Scheme 39). ${ }^{42}$

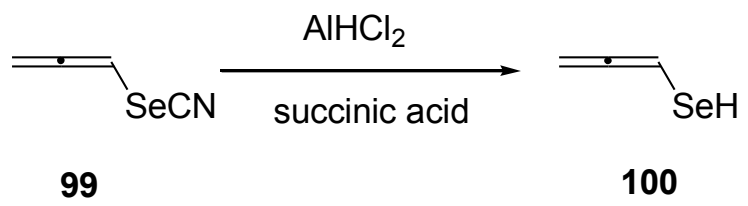

\section{Scheme 39}

\subsection{Oxidation of organic selenocyanates}

On the other hand, oxidation of selenocyanates gives the corresponding seleninic acid which in turn is very reactive and unstable. Classical hydrogen peroxide $\left(\mathrm{H}_{2} \mathrm{O}_{2}\right)$ oxidation synthetic method has been used for the synthesis of seleninic acid; however, this method is not always applicable for simple seleninic acids.

In 2014, Du et al. ${ }^{93}$ reported the oxidation of phenyl selenocyanates 101 to the corresponding amphiphilic seleninic acids $\mathbf{1 0 2}$ with in overall yields of 55\% (Scheme 40 ). ${ }^{93}$ 
<smiles>CC(C)C(=O)Nc1ccc(C#N)cc1</smiles>

101

(1)

$$
\mathrm{SO}_{2} \mathrm{Cl}_{2}
$$

reflux for $10 \mathrm{~min}$, then $\mathrm{H}_{2} \mathrm{O}$, ice bath<smiles>O=C([AlH2])Nc1ccc(S(=O)(=O)O)cc1Cl</smiles>

102

$[\mathrm{n}=6,8,10,12,14]$

\section{Scheme 40}

Dimethyldioxirane (DMDO) was also used for the synthesis of seleninic acid 104 in $70 \%$ yields via oxidation of the corresponding selenocyanates $\mathbf{1 0 3}$ in dichloromethane (Scheme 41). ${ }^{11}$

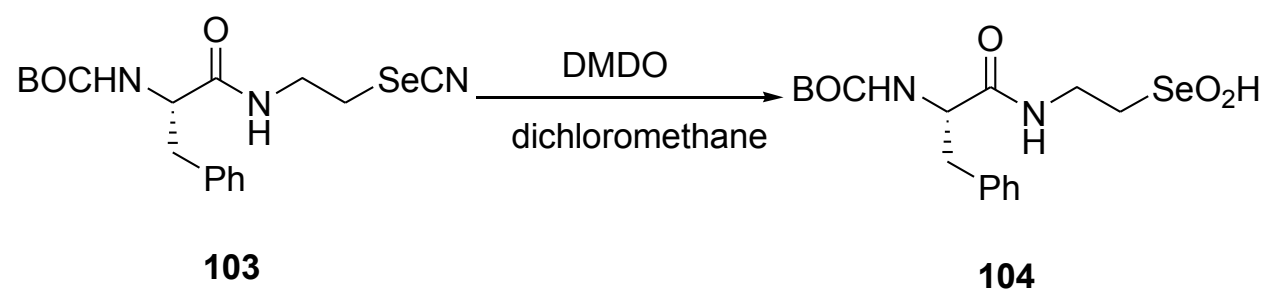

\section{Scheme 41}

\subsection{Addition reactions to the carbonitrile group}

The reaction of aniline hydrochloride salts 106 with $\alpha$-(selenocyanato)acetophenones 105 under acidic conditions afforded selenazolimine $\mathbf{1 0 7}$ in fair yields (up to 27\%). This was explained via the acid-catalyzed addition of the aniline amino group to the selenocyanate group and further cyclization with subsequent elimination of water (Scheme 42). ${ }^{18}$ 
<smiles>[R]c1ccc(C(=O)C([R])[AsH2])cc1</smiles>

105<smiles>[R]c1cc(N)cc([R])c1[R]</smiles>

106<smiles>[R]c1ccc(C(=O)C([R])[Se]/C(=N/[H])Nc2cc([R])c([R])c(I)c2)cc1</smiles><smiles>[R]c1ccc(-c2c([R])[se]c(=N)n2-c2cc([R])c([R])c([R])c2)cc1</smiles>

107

$\left[\mathrm{R}^{1}=\mathrm{H}, \mathrm{Cl}, \mathrm{Br} ; \mathrm{R}^{2}=\mathrm{H}, \mathrm{Ph} ; \mathrm{R}^{3}=\mathrm{H}, \mathrm{Cl} ; \mathrm{R}^{4}=\mathrm{H}, \mathrm{Cl}\right]$

\section{Scheme 42}

Interestingly, the reaction of $\alpha$-(selenocyanato)acetophenones 108 with diazonium salts afforded (4,5-dihydro-5-imino-4-aryl-1,3,4-selenadiazol-2-yl)(aryl)methanones 109. This was explained by the addition of the hydrazone anilino residue onto the selenocyanate group (Scheme 43). ${ }^{12}$

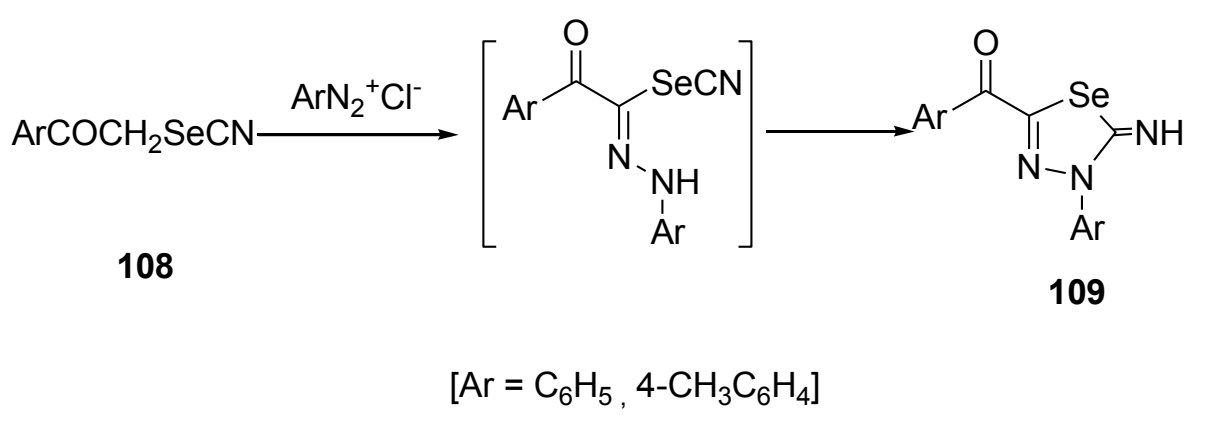

\section{Scheme 43}


Compounds containing both selenium and tetrazole ring were synthesized in high yields (7592\%) via the reactions of selenocyanates $\mathbf{1 1 0}$ with sodium azide under conditions of phase transfer catalysis in the presence of triethylammonium chloride in toluene (Scheme 44). ${ }^{46}$<smiles>[R]c1ccc([Se]#N)c([R])c1</smiles>

110
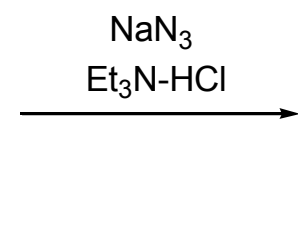

$\left[\mathrm{R}=\mathrm{H}, \mathrm{Cl}, \mathrm{CH}_{3} ; \mathrm{R}^{\prime}=\mathrm{H}, \mathrm{Cl}, \mathrm{NO}_{2}, \mathrm{COOH}, \mathrm{OCH}_{3}\right]$

\section{Scheme 44}

\subsection{Reactions accompanied with cyanide group loss}

In 2012, Brondani et al. ${ }^{94}$ reported the reaction of phenyl selenocyanate with phenylethanol derivatives 115 and tributylphosphine in toluene. In this case, reaction proceeds with the loss of the cyanide group and phenylseleno derivatives 116 were obtained in good yields (79\%- $87 \%$ ) (Scheme 45). ${ }^{94}$

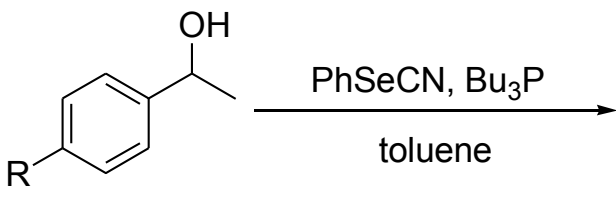

112<smiles>[R]c1ccc([Se]c2nnn[nH]2)c([R])c1</smiles>

111 


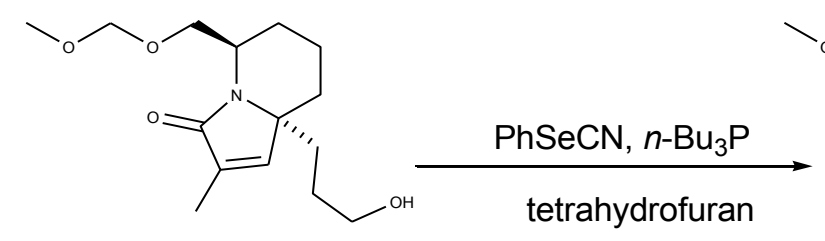

117

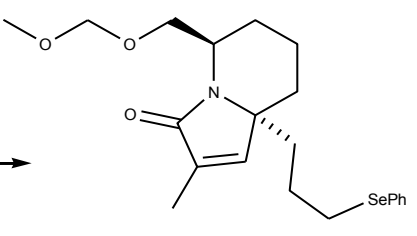

118

\section{Scheme 46}

Yamashita et al. reported that the cyanide group could be also removed from phenyl selenocyanate when reacted with primary alcohols in the presence of tributylphosphine in tetrahydrofuran (Scheme 47$)^{96}$

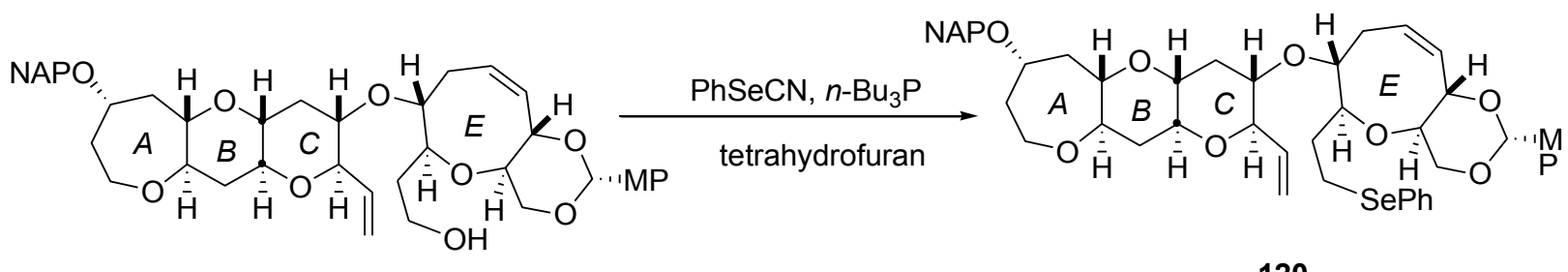

119

\section{Scheme 47}

Treatment of aldehyde $\mathbf{1 2 1}$ with $\mathrm{Bu}_{3} \mathrm{SnLi}$ and phenyl selenocyanate afforded the corresponding selenides 122 in modest yield (61\%) (Scheme 48). ${ }^{95}$<smiles>C[C@H](CC=O)[C@H]1CCC[C@]12CCCC1CC=C(C3OCCO3)CN12</smiles>

121

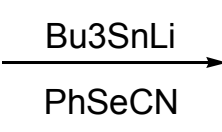

122

\section{Scheme 48}

\section{Biological Activities}

Organoselenium compounds exhibited diverse biological properties and have been used as antihypertensive, anti-bacterial, or chemopreventive anticancer agents. ${ }^{6-8}$ Among the synthetic 
selenium derivatives, organoselenocyanates have received wide attention for their better cancer chemopreventive properties as well as antioxidative and antimutagenic properties. ${ }^{97-99}$ In view of this, organic selenocyanates have recently been used in synthetic organic and metal complexes chemistry, metal extraction and in pharmaceutical and biomedical industry. ${ }^{50-57}$ Indeed, they have also shown antiparasitic (e.g. antileishmanial) and antiviral activity by improving the immune response of hosts against the parasite and the viral species. ${ }^{25,77}$

The biological activities of organoselenocyanates depend on their structural backbone and the nature of substituents on it. Extensive studies have shown that selenocyanate incorporation into the scaffold of organic compounds has enhanced the pharmacological potentials of these drugs by supplying them with new inhibitory properties. ${ }^{99}$ Furthermore, exchange of selenium by sulphur (i.e. selenocyanate to thiocyanate) in some compounds diminished the therapeutic potential of the compounds. These compounds showed multiple mode(s) of protection against cancer. These include inhibition of the Akt signaling pathway, reducing the levels of ALT and AST, upregulation of reduced glutathione levels and antioxidant enzymes, modulation of serum aspartate transaminase, alanine transaminase levels and also normalizing the hematological parameters. ${ }^{7,19-21,98}$ Organoselenocyanates are known to be metabolized to the corresponding selenols. The later are very active and can further for example bind with different metals and thus ameliorating the metal-induced hepatotoxicity. ${ }^{76-78,98}$ In this context, organoselenocyanates were considered as an efficient therapy to protect human health from metal toxicity and hazards of environmental toxicants. On the other hand, several reports have attributed the anticancer activity of these compounds to apoptosis induction via generation of reactive oxygen species induction in a prooxidant fashion. ${ }^{93}$

Besides their antitumor properties, organoselenocyanates have latterly shown an in vitro antiparasitic activity against Leishmania infantum. ${ }^{25,77}$ Interestingly, some of them possess a better activity more than the prescribed oral drugs Impavido and edelfosine. ${ }^{77}$ Their mode of action is attributed to their ability to interfere the parasites redox system. ${ }^{25,77}$

Among the most studied selenocyanates used in cancer chemotherapy, selenocoxib-1, 1,4phenylenebis(methylene)selenocyanate, diphenylmethyl selenocyanate and diphenylmethyl selenocyanate have shown to be the most efficient compounds.

1,4-Phenylenebis(methylene)selenocyanate was found to be less toxic and more effective than selenomethionin. ${ }^{103,104}$ It was found that this compound reduces the expression of cyclooxygenase-2, phospholipase A, and cyclin D1 regulated by NF-KB such as in non-small cell lung cancer cells. ${ }^{102-105}$ Furthermore, Selenocoxib-1 provides the advantage in inhibition and controlling prostate cancer growth. ${ }^{99-101}$ As another example, oral administration of diphenylmethyl selenocyanate lead to reduction of the reactive oxygen species levels which in turn reduced the chemically induced skin papilloma without causing any toxic effects. ${ }^{101,105-109}$ Moreover, diphenylmethyl selenocyanate was reported to prevent chemically induced oxidative stress and to enhance serum ALT and AST level in mice. ${ }^{107-109}$ 


\section{Conclusions}

We have summarized the recent progress in the synthesis, chemical properties, and biological importance of organoselenocyanates. The synthetic preparation methods of organoselenocyanates and their corresponding chemical properties and reactions were also described. The biological properties of this group of compounds were also issued. This knowledge will be useful in developing novel organoselenocyanates that might be of enhanced biological properties that may be developed as future drugs.

\section{Acknowledgements}

The authors thank the Egyptian Ministry of Higher Education and Mansoura University for their support.

\section{References}

1. Knoke, D.; Kottke, K.; Pohloudek-Fabini, R. Pharmazie 1973, 28, 617-32.

2. Knoke, D.; Kottke, K.; Pohloudek-Fabini, R. Pharmazie 1973, 28, 574-84.

3. Guy, R. G. Syntheses and preparative applications of thiocyanates, in Chemistry of cyanates and their derivatives; Patai, S., Ed., John Wiley, New York, 819-886, 1977. http://dx.doi.org/10.1002/9780470771532.ch2

4. Grieco, P. A.; Yokoyama, Y.; and Williams, E. J. Org. Chem. 1978, 43, 1283-1285. http://dx.doi.org/10.1021/jo00400a070

5. Lieber, E.; Rao, C. N. R.; Ramachandran, J. Spectrochim. Acta 1959, 13, 296-299. http://dx.doi.org/10.1016/0371-1951(59)80030-8

6. Nguyen, N.; Sharma, A.; Sharma, A. K.; Desai, D.; Huh, S. J.; Amin, S.; Meyers, C.; Robertson, G. P. Cancer Prev. Res. 2011, 4, 248-58. http://dx.doi.org/10.1158/1940-6207.CAPR-10-0106

7. Roy, S. S.; Ghosh, P.; Sk U. H. ; Chakraborty, P.; Biswas, J.; Mandal, S.; Bhattacharjee, A.; Bhattacharya, S. Bioorg. Med. Chem. Lett. 2010, 20, 6951-6955.

http://dx.doi.org/10.1016/j.bmcl.2009.11.017

8. Ji, W.; Jing, S.; Liu, Z.; Shen J.; Ma, J.; Zhu, D.; Cao, D.; Zheng, L.; Yao, M. Inorg. Chem. 2013, 52, 5786-5793. DOI: 10.1021/ic302628y http://dx.doi.org/10.1021/ic302628y

9. Toshimitsu, A.; Uemura, S. Organic Selenium and Tellurium Compounds, Organic selenocyanates, tellurocyanates and related compounds. Patai's chemistry of functional groups, John Wiley \& Sons Ltd. 2, 14, 541-590, 1987. 
10. Guillemin, J. C. Curr. Org. Chem. 2011, 15, 1670-1687.

http://dx.doi.org/10.2174/138527211795656642

11. Abdo, M.; Sun, Z.; Knapp, S. Molecules 2013, 18, 1963-1972.

http://dx.doi.org/10.3390/molecules18021963

12. Abdelhamid, A. O.; Fahmi, A. A.; Baaui, B. S. J. Het. Chem. 2012, 49, 1098-1107. http://dx.doi.org/10.1002/jhet.945

13. Ibrahim-Ouali, M.; Romero, E.; Bouleghlem, H. Tetrahedron 2011, 67, 3668-3676. http://dx.doi.org/10.1016/j.tet.2011.03.080

14. Desai, D.; Salli, U.; Vrana, K. E.; Amin, S. Bioorg. Med. Chem. Lett. 2010, 20, 2044-2047. http://dx.doi.org/10.1016/j.bmcl.2009.07.068

15. Levason, W.; Manning, J. M.; Nirwan, M.; Ratnani, R.; Reid, G.; Smith, H. L.; Webster, M. Dalton Trans. 2008, 3486-3492. http://dx.doi.org/10.1039/b718950h

16. Ju-Nam, Y.; Allen, D. W.; Gardiner, P. H. E.; Light, M. E.; Hursthouse, M. B.; Bricklebank, N. J. Organometallic Chem. 2007, 692, 5065-5070. http://dx.doi.org/10.1016/j.jorganchem.2007.07.038

17. Cui, XR; Takahashi, K.; Shimamura, T.; Koyanagi, J.; Komada, F., Saito, S. Chem. Pharm. Bull. 2008, 56, 497-503.

http://dx.doi.org/10.1248/cpb.56.497

18. Bodtke, A.; Kandt, M.; Pfeiffer, W. D.; Langer, P. Phosphorus, Sulfur, Silicon 2007, 182, 209-217. http://dx.doi.org/10.1080/10426500600892685

19. Sk, U. H.; Bhattacharya, S. Env. Toxicol. Pharmacol. 2006, 22, 298-308. http://dx.doi.org/10.1016/j.etap.2006.04.004

20. Sk, U. H.; Sharma, A. K.; Ghosh, S.; Bhattacharya, S. Eur. J. Med. Chem. 2010, 45, 32653273.

http://dx.doi.org/10.1016/j.ejmech.2010.04.001

21. Roy, S. S.; Ghosh, P.; Sk, U. H.; Chakraborty, P.; Biswas, J.; Mandal, S.; Bhattacharjee, A.; Bhattacharya, S.; Bioorg. Med. Chem. Lett. 2010, 20, 6951-6955. http://dx.doi.org/10.1016/j.bmcl.2009.11.017

22. Mamedov, V. A.; Saifina, D. F.; Berdnikov, E. A.; Rizvanov, I. Kh. Russ. Chem. Bull. Int. Ed. 2007, 56, 2127-2130. http://dx.doi.org/10.1007/s11172-007-0334-3

23. Jacob, L. A.; Matos, B.; Mostafa, C.; Rodriguez, J.; Tillotson, J. K. Molecules 2004, 9, 622626. http://dx.doi.org/10.3390/90800622

24. Krishnegowda, G.; Gowda, A. S. P.; Tagaram, H. R. S.; Carroll, K. F. SO.; Irby, R. B.; Sharma, A. K.; Amin, S. Bioorg. Med. Chem. 2011, 19, 6006-6014. http://dx.doi.org/10.1016/j.bmc.2011.08.044

25. Plano, D.; Baquedano, Y.; Moreno-Mateos, D.; Font, M.; Jiménez-Ruiz, A.; Palop, J. A.; 
Sanmartìn, C. Eur. J. Med. Chem. 2011, 46, 3315-3323.

http://dx.doi.org/10.1016/i.ejmech.2011.04.054

26. Riague, El. H.; Guillemin, J. C. Organometallics 2002, 21, 68-73.

27. Sharpless, K. B.; Lauer, R. F. J. Am. Chem. Soc. 1972, 94, 7154-7155. http://dx.doi.org/10.1021/ja00775a050

28. Sharpless, K. B.; Lauer, R. F. J. Org. Chem. 1972, 37, 3973-3974. http://dx.doi.org/10.1021/jo00797a058

29. Lauer, R. F.; Ph.D. Thesis, Massachusetts Institute of Technology, U. S. A. 1974.

30. Banert, K.; Toth, C. Angew. Chem., Int. Ed. Engl., 1995, 34, 1627-1629.

31 Kotani, M.; Shigetomi, Y.; Imada, M.; Ōki, M.; Nagaoka M. Heteroatom Chemistry 1997; 8, 35-43. DOI:10.1002/(SICI)1098-1071(1997)8:13.3.CO;2-P

32 Frolov, A. N.; Smirnov, E. V.; Kul'bitskaya, O. V.; El'tsov, A. V. Zh. Org. Khim. 1980, 16, 2302-2309.

33. Paulmier, C.; Outurquin, F.; J. Heterocyclic Chem. 1980, 20, 113-119.

34. Suzuki, H.; Shinoda, M.; Synthesis 1977, 9,640-641. http://dx.doi.org/10.1055/s-1977-24514

35. Suzuki, H.; Miyoshi, K.; Shinoda, M.; Bull. Chem. Soc. Japan 1980, 53, 1765-1766. http://dx.doi.org/10.1246/bcsj.53.1765

36. Baig, N. B. R.; Chandrakala, R. N.; Sudhir, V. S.; Chandrasekaran, S. J. Org. Chem., 2010, 75, 2910-2921.

37 Quan, HJ.; Koyanagi, J.; Komada, F.; Saito, S. Eur. J. Med. Chem. 2005, 40, 662-673.

38 Jin, GZ.; Quan, HJ.; Koyanagi, J.; Takeuchi, K.; Miura, Y.; Komada, F.; Saito, S. Cancer Lett. 2005, 218, 15-20.

39. Viñas-Bravo, O.; Martinez-Pascual, R.; Vega-Baez, J. L.; Gómez-Calvario, V.; SandovalRamírez, J.; Montiel-Smith, S.; Meza-Reyes, S.; Rosas, A. LD.; Martínez-Montiel, M.; Reyes, M.; Ruiz, J. A. Steroids 2012, 77, 59-66.

40. Desai, D.; Sinha, I.; Null, K.; Wolter, W.; Suckow, M. A.; King, T.; Amin, S.; Sinha, R. Int. J. Cancer 2010, 127, 230-238.

\section{http://dx.doi.org/10.1002/ijc.25033}

41. Werz, D. B.; Fischer, F. R.; Kornmayer, S. C.; Rominger, F.; Gleiter, R. J. Org. Chem. 2008, 73, 8021-8029. http://dx.doi.org/10.1021/jo801378p

42. Møllendal, H.; Mokso, R.; Guillemin J. C. J. Phys. Chem. A. 2008, 112, 3053-3060. http://dx.doi.org/10.1021/jp7112973

43. Guillemin, J. C.; Bajor, G.; Riague, El. H.; Khater, B.; Veszprémi, T. Organometallics, 2007, $26,2507-2518$. http://dx.doi.org/10.1021/om061067j

44. Malins, L. R.; Payne R. J. Org. Lett. 2012, 14, 3142-3145. http://dx.doi.org/10.1021/o13012265 
45. Yavuz, S.; Disli, A.; Yildirir, Y.; Türker, L. Molecules 2005, 10, 1000-1004. http://dx.doi.org/10.3390/10081000

46. Özkan, H.; Yavuz, S.; Disli, A.; Yildirir, Y.; Türker, L. Heteroat. Chem. 2007, 18, 255-258. http://dx.doi.org/10.1002/hc.20293

47. Nair, V.; Augustine, A.; George, T. G. Eur. J. Org. Chem. 2002, 2363-2366. http://dx.doi.org/10.1002/1099-0690(200207)2002:14<2363::AID-EJOC2363>3.0.CO;2-7

48. Guram, A. S. Synlett 1993, 4,259-261. http://dx.doi.org/10.1055/s-1993-22423

49. Blanck, S.; Maksimoska, J.; Baumeister, J.; Harms, K.; Marmorstein, R.; Meggers, E. Angew. Chem. Int. Ed. 2012, 51, 5244-5246. http://dx.doi.org/10.1002/anie.201108865

50. Ross, T. M.; Moubaraki, B.; Neville, S. M.; Batten, S. R.; Murray, K. S. Dalton Trans. 2012 , $41,1512-1523$.

http://dx.doi.org/10.1039/c1dt11597a

51. Klingele, J.; Kaase, D.; Klingele, M. H.; Lach, J. Dalton Trans., 2012, 41, 1397-1406. http://dx.doi.org/10.1039/c1dt11396h

52. Wilbuer, A.; Vlecken, D. H.; Schmitz, D. H.; Kräling, K.; Harms K., Bagowski, C. P.; Meggers, E. Angew. Chem. Int. Ed. 2010, 49, 3839-3842.

http://dx.doi.org/10.1002/anie.201000682

53. Kastl, A.; Wilbuer, A.; Merkel, A. L.; Feng, L.; Fazio, P. D.; Ocker, M.; Meggers, E. Chem. Commun. 2012, 48, 1863-1865.

http://dx.doi.org/10.1039/c1cc15378a

54. Blanck, S.; Cruchter, T.; Vultur, A.; Riedel, R.; Harms, K.; Herlyn, M.; Meggers, E. Organometallics 2011, 30, 4598-4606.

http://dx.doi.org/10.1021/om200366r

55. Odabasioglu, S.; Kurtaran, R.; Azizoglu, A.; Kara, H.;Öz. S.; Atakol, O. Cent. Eur. J. Chem, 2009, 7, 402-409.

56. Bortoluzzi, M.; Paolucci, G.; Pitteri, B.; Vavasori, A.; Bertolasi, V. Organometallics 2009, 28, 3247-3255.

http://dx.doi.org/10.1021/om900146a

57. Baker, M. V.; Barnard, P. J.; Brayshaw, S. K.; Hickey, J. L.; Skelton, B. W.; White, A. H. Dalton Trans. 2005, 37-43.

http://dx.doi.org/10.1039/b412540a

58. Kachanov, A. V.; Slabko, O. Y.; Baranova, O. V.; Shilova, E. V.; Kaminskii, V. A. Tet. Lett. 2004, 45, 4461-4463.

http://dx.doi.org/10.1016/j.tetlet.2004.04.071

59. Goswami, S.; Maity, A. C.; Das, N. K.; Sen, D.; Maity, S. Synth. Commun. 2009, 39, 407-415.

http://dx.doi.org/10.1080/00397910802374141 
60. Kaminskii, V. A.; Slabko, O. Y.; Kachanov, A. V.; Buhvetskii B. V.; Tetrahedron Lett. 2003, 44, 139-140.

http://dx.doi.org/10.1016/S0040-4039(02)02509-1

61. Burchell, C. J.; Kilian, P.; Slawin, A. M. Z.; Woollins J. D.;Tersago, K.; Alsenoy, C. A.; Blockhuys, F. Inorg. Chem. 2006, 45, 710-716.

http://dx.doi.org/10.1021/ic0515103

62. Nefedov, V. A.; Tarygina, L. K.; Kryuchkova, L. V.; Ryabokobylko, Y. S. Zh. Org. Khim. 1981, 17, 570-584.

63. Chao, T. H.; Lyons, R. E. Proc. Indiana Acad. Sci. 1937, 46, 105-106.

64. Belostotskii, A. M.; Lexner, J.; Hassner, Tet. Lett. 1999, 40, 1181-1184.

http://dx.doi.org/10.1016/S0040-4039(98)02559-3

65. Aynsley, E. E.; Greenwood, N. N.; Sprague, M. J. J. Chem. Soc. 1965, 2395-2402. http://dx.doi.org/10.1039/jr9650002395

66. Tomoda, S.; Takeuchi, Y.; Nomura, Y. Chem. Lett. 1981, 1069-1070.

http://dx.doi.org/10.1246/cl.1981.1069

67. Kang, Y. H.; Kice, J. L.; J. Org. Chem. 1984, 49, 1507-1511.

http://dx.doi.org/10.1021/jo00183a006

68. Trujillo, C.; Mo, O.; Yảńez, M.; Silvi B. J. Chem. Theory Comput. 2008, 4, 1593-1599. http://dx.doi.org/10.1021/ct800178x

69. Dushenko, G. A.; Mikhailov, I. E.; Dorogan, I. V.; Minyaev, R. M.; Hakam, N.; Zschunke, A.; Minkin, V. I. Mendeleev Commun. 1995, 5, 213-215. http://dx.doi.org/10.1070/MC1995v005n06ABEH000530

70. Banert, K.; Toth, C. Angew. Chem. Int. Ed. Engl. 1995, 34, 1627-1629. http://dx.doi.org/10.1002/anie.199516271

71. Tarantelli, T.; Leonesi, D. Annali di Chimica (Rome, Italy), 1963, 53, 1113-1122.

72. Koch, R.; Finnerty, J. J.; Murali, S.; Wentrup, C. J. Org. Chem. 2012, 77, 1749-1759. http://dx.doi.org/10.1021/jo2023069

73. Dushenko, G. A.; Mikhailova, O. I.; Mikhailov, I. E.; Minyaev, R. M.; Minkin, V. I. Russ. Chem. Bull. Int. Ed. 2009, 58, 1713-1723.

http://dx.doi.org/10.1007/s11172-009-0237-6

74. Heimgartner, H.; Zhou, Y.; Atanassov, P. K.; Sommen. G. F. Phosphorus, Sulfur, and Silicon, 2008, 183, 840-855.

http://dx.doi.org/10.1080/10426500801898135

75. Ghassemian, A.; Vila-Farres, X.; Alewood, P. F.; Durek, T. Bioorg. Med. Chem. 2013, 21, 3473-3478.

http://dx.doi.org/10.1016/j.bmc.2013.03.076

76. Marciniec, K.; Latocha, M.; Boryczka, S.; Kurczab, R. Med. Chem. Res. 2014. 10.1007/s00044-014-0922-3.

http://dx.doi.org/10.1007/s00044-014-0922-3 
77. Baquedano, Y.; Moreno, E.; Espuelas S.; Nguewa P.; Font M.; Gutierrez K. J.; JiménezRuiz, A.; Palop J. A.; Sanmartína, C. Eur. J. Med. Chem. 2014, 74, 116-123.

http://dx.doi.org/10.1016/j.ejmech.2013.12.030

78. Roy, S. S.; Chakraborty, P.; Bhattacharya, S. Eur. J. Med. Chem. 2014, 73, 195-209. doi: 10.1016/j.ejmech.2013.12.015.

http://dx.doi.org/10.1016/j.ejmech.2013.12.015

79. Krief, A.; Dumont, W.; Delmotte, C. Angew. Chem. Int. Ed, 2000, 39, 1669-1672.

http://dx.doi.org/10.1002/(SICI)1521-3773(20000502)39:9<1669::AIDANIE1669>3.0.CO;2-

80. Block, E.; Birringer, M.; DeOrazio, R.; Fabian, J.; Glass, R. S.; Guo, C.; He, C.; Lorance, E.; Qian, Q.; Schroeder, T. B.; Shan, Z.; Thiruvazhi, M.; Wilson, G. S.; Zhang, X. J. Am. Chem. Soc. 2000, 122, 5052-5064. http://dx.doi.org/10.1021/ja994134s

81. Gosselck, J.; Wolters, E. Chem. Ber. 1962, 95, 1237-1244. http://dx.doi.org/10.1002/cber.19620950522

82. Back, T. G.; McPheelb, D. J. J. Org. Chem. 1984, 49, 3842-3843. http://dx.doi.org/10.1021/jo00194a038

83. Renson, M.; Piette, J. L. Bull. Soc. Chim. Belg. 1964, 73, 507-517 . http://dx.doi.org/10.1002/bscb.19640730518

84. Sevrin, M.; Krief, A. J.; Chem. Soc. Chem. Commun. 1980, 656. http://dx.doi.org/10.1039/c39800000656

85. Kondo, N.; Fueno, H.; Fujimoto, H.; Makino, M.; Nakaoka, H.; Aoki, I.; Uemura, S. J. Org. Chem. 1994, 59, 5254.

http://dx.doi.org/10.1021/jo00097a029

86. Tomoda, S.; Takeuchi, Y.; Nomura, Y. Tet. Lett. 1982, 23, 1361-1364. http://dx.doi.org/10.1016/S0040-4039(00)87105-1

87. Tomoda, S.; Takeuchi, Y.; Nomura, Y. Chem. Lett. 1982, 1733-1734. http://dx.doi.org/10.1246/c1.1982.1733

88. Tomoda, S.; Takeuchi, Y.; Nomura, Y. Chem. Lett., 1981, 1715-1718. http://dx.doi.org/10.1246/cl.1981.1715

89. Tomoda, S.; Takeuchi, Y.; Nomura, Y. Chem. Soc. Chem. Commun., 1982, 871-872.

90. Asamizu, T.; Henderson, W.; Nicholson, B. K.; Hey-Hawkins, E. Inorg. Chimi.Acta. 2014, 414, 181-190. http://dx.doi.org/10.1016/j.ica.2014.01.049

91. Paetzold, R.; Lienig, D. Z. Anorg. Allgem. Chem. 1965, 335, 289-296. http://dx.doi.org/10.1002/zaac.19653350509

92. Kozlov, V. V.; Suvorova, S. E. Zh. Obshch. Khim. 1961, 31, 3034-3037.

93. Du, P.; Viswanathan, U. M.; Xu, Z.; Ebrahimnejad, H.; Hanf, B.; Burkholz, T.; Schneider, M.; Bernhardt, I.; Kirsch, G.; Jacob, C. J. Hazardous Mat. 2014, 269, 74-82. http://dx.doi.org/10.1016/j.jhazmat.2014.01.014 
94. Brondani, P. B.; Guilmoto, N. M. A. F.; Dudek, H. M.; Fraaije, M. W.; Andrade, L. H. Tetrahedron 2012, 68, 10431-10436.

http://dx.doi.org/10.1016/j.tet.2012.09.087

95. Liu, D.; Acharya, P. H.; Yu, M.; Wang J.; Yeh, V. S. C.; Kang S.; Chiruta C.; Jachak S. M.; Clive D. L. J. J. Org. Chem. 2009, 74, 7417-7428.

http://dx.doi.org/10.1021/jo901481n

96. Yamashita, S.; Uematsu, R.; Hirama, M. Tetrahedron 2011, 67, 6616-6626. http://dx.doi.org/10.1016/j.tet.2011.05.080

97. Mati, S. S.; Roy, S. S.; Chall, S.; Bhattacharya, S.; Bhattacharya, S. C. J. Phys. Chem. B. 2013, 117, 14655-14665.

http://dx.doi.org/10.1021/jp4090553

98. Facompre, N. D.; El-Bayoumy, K.; Sun Y. W.; Pinto J. T.; Sinha R. Cancer Prev. Res. 2010, 3, 975-984.

http://dx.doi.org/10.1158/1940-6207.CAPR-10-0054

99. Gowda, R.; Madhunapantula, S. V.; Desai, D.; Amin S.; Robertson G. P. Mol. Cancer Ther. 2013, 12, 3-15.

http://dx.doi.org/10.1158/1535-7163.MCT-12-0492

100. Das, R. K.; Ghosh, S.; Sengupta, A.; Das, S.; Bhattacharya, S. Eur. J. Cancer Prev., 2004, 13, 411-417.

http://dx.doi.org/10.1097/00008469-200410000-00009

101. Das, R. K.; Hossain, S. K. U.; Bhattacharya, S. Cancer Lett., 2005, 230, 90-101.

http://dx.doi.org/10.1016/j.canlet.2004.12.021

102. Emmert, S. W.; El-Bayoumy, K.; Das, A.; Sun, Y. W.; Amin, S.; Desai, D.; Aliaga, C.; Richie J. P. Jr. Free Radic. Biol. Med. 2012, 15, 2064-71.

http://dx.doi.org/10.1016/j.freeradbiomed.2012.03.018

103. Facompre, N. D.; El-Bayoumy, K.; Sun Y. W.; Pinto J. T.; Sinha R. Int. J. Cancer. 2012, 1, 2134-2142.

http://dx.doi.org/10.1002/ijc. 27468

104. Chen, K. M.; Sacks, P. G.; Spratt, T. E.; Linm J. M.; Boyiri, T.; Schwartz, J.; Richie, J. P.; Calcagnotto, A.; Das, A.; Bortner, J.; Zhao, Z.; Amin, S.; Guttenplan, J.; El-Bayoumy, K.; Biochem. Biophys. Res. Commun. 2009, 22, 151-155.

http://dx.doi.org/10.1016/j.bbrc.2009.03.145

105. Narayanan, B. A.; Narayanan, N. K.; Desai, D.; Pittman, B.; Reddy, B. S. Carcinogenesis, 2004, 25, 2443-2449.

http://dx.doi.org/10.1093/carcin/bgh252

106. Chakraborty, P.; Roy, S. S.; Sk, U. H.; Bhattacharya, S. Free Radical Res. 2011, 45, 17787.

http://dx.doi.org/10.3109/10715762.2010.52115 
107. Chakraborty, P.; Sk, U. H.; Bhattacharya, S. Cancer Chemother Pharmacol. 2009, 64, 971-980.

http://dx.doi.org/10.1007/s00280-009-0950-8

108. Das, R. K.; Sk, U. H.; Bhattacharya, S. J. Appl Toxicol. 2007, 27, 527-37.

http://dx.doi.org/10.1002/jat.1230

109. Das, R. K.; Banerjee, S.; Bhattacharya, S.; Exp Toxicol Pathol. 2007, 58, 351-60.

http://dx.doi.org/10.1016/j.etp.2006.10.003 


\section{Authors' Biographies}

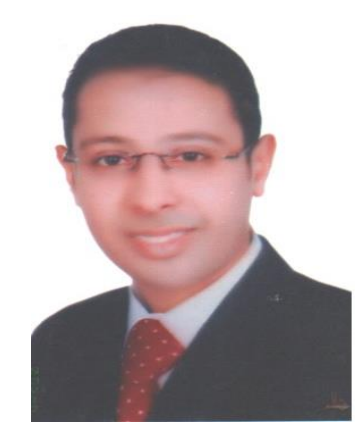

Saad Shaaban was born in Mansoura, Egypt, in 1981. He studied chemistry at Mansoura University and he received his MSc from the same university in 2003. He obtained his PhD in 2011 from the Bioorganic Chemistry Department of the School of Pharmacy of Saarland University, Germany. He has served as a postdoctoral researcher in Professor Alexander Doemling's group at Groningen University, The Netherlands, and in Professor Ludger Wessjohann's group at the Leibniz Institute of Plant Biochemistry at Halle, Germany. His main research interests lie predominantly in the field of synthetic organic chemistry, in particular heterocyclic chemistry and the chemistry of organoselenium compounds.

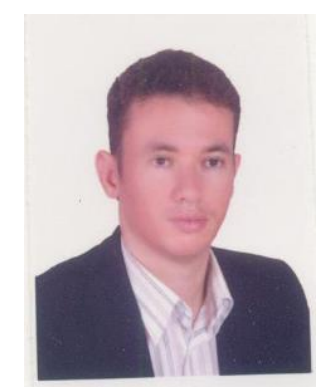

Mahmoud Arafat was born in Mansoura, Egypt, in 1978. He studied chemistry at Mansoura University and he received his bachelor degree from the same university in 2000. He also received his M.Sc from the same university in 2014 under the supervision of Professor H. H. Zoorob , Professor Wafaa Salama Hamama and Dr. Saad Shaaban. He has worked as laboratory specialist in Mansoura University. His main research interests lay in the field of synthetic organic chemistry, in particular heterocyclic chemistry and the chemistry of organoselenium compounds. 


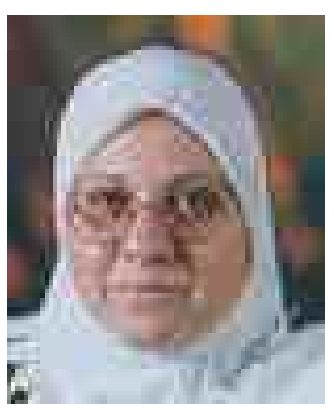

Wafaa Salama Hamama graduated from Faculty of Science, Mansoura University where she was awarded the MSc and PhD in Chemistry from Faculty of Science, Mansoura University in 1978 and 1983, respectively. She was appointed Assistant Professor in 1988 then full Professor in 2001. She worked in Um-El Koura University in Saudi Arabia from 1990 to 1996. She was awarded a postdoctoral fellowship in 2009 at (DFG) with Prof N.Khunert, Jacobs University, Germany. Her research focused on the development in the synthesis of heterocyclic organic compounds of different classes having pharmacological activity. She was chosen to be a member of the Promotion Committee of the Professors and Assistant Professors in Organic Chemistry 2013-2015. 